\title{
TINKERING WITH THE CALIFORNIA BAIL SYSTEM
}

Two words express the bail system's purpose in the administration of criminal justice: release and return. The system is intended to release from pretrial detention as many arrestees as possible while providing reasonable assurance that they will return promptly for their trials.

The bail system is primarily a statutory beast,' with an ancestry extending back more than 700 years. ${ }^{2}$ The California legislature has tinkered with it at every session in the past decade in an effort to correct its problems. ${ }^{3}$ Nevertheless, several problems still require legislative action and many critics feel that there are basic defects in the bail system which no amount of patchwork, repairs, and modifications can correct. ${ }^{4}$ Some feel that the only solution to the alleged inherent in-

'See CAL. Pen. Code $\S \S 1268-1317$ (West 1956), as amended, (West Supp. 1967).

${ }^{2}$ Although references to a bail system are found in Plato, see Foote, The Bail System and Equal Justice, 23 FED. Probation 43 (Sept. 1959), the definite ancestor of modern bail law is the Statute of Westminster of 1275 which prescribed those offenses for which bail was available. From the Massachusetts Declaration of Liberties in 1641, the Northwest Territories Ordinance of 1787, the Federal Judiciary Act of 1789, up to the Federal Bail Reform Act of 1966, bail procedures and bail reforms in this country have come primarily through legislation. See Foote, The Coming Constitutional Crisis in Bait, 113 U. PA. L. REv. 959 (1965) [hereinafter cited as Foote, Constitutional Crisis in Bail]. See generally E. DE HAAs, ANTIQUITIES OF BAIL: ORIGIN AND Historical Development in Criminal Cases to the Year 1275 (1940).

${ }^{3}$ See, e.g., (in chronological order) ch. 287, [1956-57] Cal. Stats. 4744 (Assembly concurrent resolution no. 67 directing the California Law Revision Commission to study the "archaic and extremely confusing" laws relating to bail and to recommend simplifications); ch. 2324, [1956-57] Cal. Stats. 4049 (rewrote Penal Code $\S 1269 \mathrm{~b}$ to authorize jailors to release defendants who post the amount of bail specified on the arrest warrant or misdemeanor bail schedulc); ch. 1396, [1958-59] Cal. Stats. 3674 (amended Penal Code $\S 1269$ b to provide for an "all other misdemeanors not specified" category on misdemeanor bail schedules); ch. 2185, [1960-61] Cal. Stats. 4526 (added Penal Code $\S 847.5$ regulating the recapture in California by bondsmen of fugitives admittcd to bail in another state); ch. 2014, [1962-63] Cal. Stats. 4113 (amended Penal Code $\S 1305$ to change the magistrate's power to discharge the forfeiture of a bail bond from a discretionary "may discharge" to a mandatory "shall discharge"); ch. 206, [1964-65] Cal. Stats. 1171 (amended Penal Code $§ 1305$ to add a third procedure for securing the remission of a forfeited bail bond); ch. 1926, [1964.65] Cal. Stats. (amended Penal Code $\S 1305$ to extend the period within whieh the court can set aside a bail forfeiture from 90 days to 180 days).

${ }^{4}$ See generally D. FREED \& P. WALD, BAIL IN THE UNITED STATES: 1964 6-22 (1964) [hereinafter cited as Freed \& Wald]; R. Goldfarb, Ransom: A Critique of the AMERiCan Bail System 6-19 (1965) [hereinafter cited as Goldfarb]; AtTORney General's COMm. ON POVERTy aNd the Administration of Federal Criminal Justice, Report on POVERTy and the Administration of Federal Criminal Justice ch. 111 (1963) [hcreinafter cited as 1963 ATt'Y Gen's ReP.]; Hearings on S. 2838, S. 2839, and S. 2840 Before the Subcomm. on Constilutional Rights and the Subcomm. on Improvements in Judiciai Machinery of the Senute Comm. on the Judiciary. 88th Cong., 2d Sess. 27 (1964) (testimony of Attorney General Robert Kennedy) (hereinafter cited as 1964 Senate Hearings]; Staff of Senate Comm. on the Judiciary, 88th Cong., 2d Sess., Report on Constitutional Rights and Federal Bail Procedures 3 (Comm. Print 1965) [hereinafter cited as 1965 SENATE STAFF RePort]; Hearings on H. R. 3576 Before a Subcomm. of the House Comm. on the Judiciary, 89th Cong., 2d Sess. 17 (1966) (testimony of Representativc 
equities of the present system is its complete replacement with one or more alternative pretrial release systems. In response to this suggestion, Congress and several state legislatures have changed their pretrial release systems to eliminate or substantially reduce the importance of release on bail. ${ }^{5}$

The function of the bail system and the bail bondsman is to provide a means of reconciling the conflicting interests of the defendant, who desires to remain free of pretrial detention, and the state, which desires the defendant to appear promptly for his trial. ${ }^{6}$ Under the bail system, the defendant secures a conditional pretrial release from custody-the condition being that he deposit with the court a specified sum of money which is subject to forfeiture in the event he does not appear for his trial.

In a large number of cases, the defendant does not deposit his own money with the court. Instead, a professional bail bondsman posts a surety bond and assumes the risk of losing his deposit in the event the defendant does not appear. The bondsman will often insist that the defendant or his relatives and friends put up collateral security, perhaps to the full amount of the bond, which will provide some protection to the bondsman in the event of a forfeiture. ${ }^{7}$ The bail system operates to insure

William McCulloch of Ohio) [hereinafter cited as 1966 House Hearings]; Cobb, Bondsmen Fatten on Needless Bail, 9 PANEL 39 (1931); Foote, Compelling Appearance in Court: Administration of Bail in Philadelphia, 102 U. PA. L. REv. 1031 (1954) [hereinafter cited as Foote, Bail in Philadelphia]; Hayes, Contracts to Indemnify Bail in Criminal Cases, 6 Fordham L. Rev. 387, 407 (1937) [hereinafter cited as Hayes]; Paulsen, Pretrial Release in the United States, 66 Colum. L. REv. 109 (1966) [hereinafter cited as Paulsen]; Silverstein, Bail in the State Courts-A Field Study and Report, 50 MinN. L. Rev. 621 (1966); Sturz, An Alternative to the Bail System, 26 FED. Probation 49 (Dec. 1962); Sweet, Bail or Jail, 19 Record of N.Y.C.B.A. 11 (1964) [hereinafter cited as Sweet]; Comment, $A$ Study of the Administration of Bail in New York City, 106 U. PA. L. REV. 685 (1958) [hereinafter cited as Comment, Bail in New York]; Comment, The Administration of Bail, 41 Yale L.J. 293, 298 (1931) [hereinafter cited as Comment, Administration of Bail]; Comment, Bail: An Ancient Practice Reexamined, 70 YALE L.J. 966 (196l) [hereinafter cited as Comment, Ancient Practice Reexamined]; interview with Bayard Rustin, 13 PLAYBoy, March 1966 , at 52 .

${ }^{5}$ See, e.g., Federal Bail Reform Act of 1966, 18 U.S.C. $\S \S 3146-52$ (Supp. 11, 1965-66); lLL. ANN. STAT. ch. 38, \$\$110-1 to 110-15 (Smith-Hurd 1964).

'See Goldfarb, supra note 4, at 238; Foote, The Bail System and Equal Justice, 23 FED. Probation 43 (Sept. 1959); Hayes, supra note 4, at 396; Note, An Alternative to the Bail System: Penal Code Section 853.6, 18 Hastings L.J. 643, 648 (1967) [hereinafter cited as Note, Alternative to Bail]; Comment, Preventive Detention Before Trial, 79 Harv. L. Rev. 1489 (1966).

Although this Comment will discuss only bail practices and procedures in the administration of California criminal law, there is also a form of bail which may be required in civil cases. CAL. Civ. PRo. CODE $\$ \$ 477-504,1215$ (West 1954). See generally GoldFaRB, supra note 4, at 20-21.

There is also a provision that a material witness in a criminal prosecution may be required to post a $\$ 500$ bond, conditioned upon his appearing and testifying under penalty of forfeiture. $C_{A L}$. Pen. CODE $\S 878$ (West 1956).

'See Surety Association of America, The Surety Bond in Court Proceedings 26 (1954); 1964 Senate Hearings, supra note 4, at 80 (testimony of George Will, Executive Director of 
the defendant's presence at his trial by creating a financial interest in the performance of his obligations in both the bail bondsman, whose bond is at stake, and in the defendant's relatives and friends, who stand to lose the collatcral they have pledged to the bondsman. ${ }^{8}$

In essence, the bail bondsman acts as a broker to accomodate the conflicting interests of the state and the arrestee. The bondsman performs a service for the arrestee by quickly bailing him out of jail ${ }^{9}-$ for a price. ${ }^{10}$ The bondsman performs a service for the state by promising to return the arrestee to court at a specified time, thereby rclieving the state of the expense of incarcerating large numbers of persons prior to their trials."

Most defendants released on bail appear in court on time.12 However, it is difficult to find proof that it is the bail system itself which is the major factor in insuring the presence of thc accused at his trial. Most defendants released on their own recognizance ${ }^{13}$ also appear on schedule. ${ }^{14}$ Comprehensive statistics on the number of bail forfeitures

the American Society of Professional Bail Bondsmen); 1966 House Hearings, supra note 4, at 90 (letter from Rochelle Bail Agency, Yonkers, N.Y.).

${ }^{8}$ See Note, Criminal Procedure-Some Problems in the Administration of Bail, 44 KY. L.J. 447, 453 (1956); Northern California Association of Bail Bondsmen, Summary of Testimony to he Presented to the Legislature in Opposition to A.B. 1966, A.B. 2024, A.B. 2025, and S. B. 1265, at 7 (1965) (on file with the California Law Review) [hereinafter cited as California Bondsmen's Bail Testimonyl. But see GoldFarB, supra note 4, at 243.

"The bondsman is hardworking mostly when his money is involved; he is available night and day to sell a bond. . . And without the omnipresent bondsınan a phone call away from the police station, many defendants would be exposed to incarceration for some avoidable hours." GOLDFARD, supra note 4, at 101. See Brodie, Bail in California . . 1964, at 23 (1964) (mimeo prepared by Northern California Bail Bondsmen's Association, on file with the California Law Review) [hercinafter cited as Brodie, Bail in Californial; Hearings on S. 2855 Before the Subcomm. on Constitutional Rights and the Subcomm. on Improvements in Judicial Machinery of the Senate Comm. on the Judiciary, 89th Cong., 2d Sess. 108 (1966) (testimony of Lawrence Speiser of the American Civil Liberties Union) [hereinafter cited as 1966 Senate Hearings on Fugitive Bailees]. But see Note, Alternative to Bail, supra note 6, at 656.

${ }^{10}$ Generally $10 \%$ of the value of the bond. FREED \& WALD, supra note 4, at 23-24.

"See Hearings on S. 1357, S. 646, S. 647, and S.648 Before the Subcomm. on Constitutional Rights and the Subcomm. on Improvements in Judicial Machinery of the Senate Comm. on the Judiciary, 89th Cong., Ist Sess. 35 (1965) (țestimony of Assistant Attorney General Ramsey Clark) [hereinafter cited as 1965 Senate Hearings]; $i d$. at 127 (testimony of Carroll Stewart, Kentucky bail bondsman); id. at 293 (Edward Foote, Twelve Judicial Views on Bail).

${ }^{12}$ Approximately three percent of the people released on bail fail to appear at their trials. FREED \& WALD, supra note 4, at 29; 1966 House Hearings, supra note 4, at 21 (testimony of Assistant Attorney General Ramsey Clark).

${ }^{13}$ An arrestee released on his own recognizance is released on his promise to return, and need not post a bail bond. See text accompanying notes 88-101 infra for further discussion of this release procedure.

${ }^{14}$ See, e.g., McCarthy, Practical Results of Bail Reform, 29 Fed. Probation 10, 12 (Scpt. 1965) [hereinafter cited as McCarthy] (approximately three percent of those released on their own recognizance in the District of Columbia failed to appear for their trials). 
and remissions ${ }^{15}$ in California, if available, might provide proof of the effectiveness of the return function of the bail system. Analysis of such statistics might indicate that the bondsman does perform a uniquely useful function by locating absent defendants and producing them in court or by providing an acceptable excuse to justify or mitigate the absence. If this is the case, retention of the bail system, with modifications to correct unnecessary hardships or widespread abuses, is justified. However, if the bail system actually has little added deterrent effect on the number of defendants who eventually appear for trial after release from pretrial detention, then the clamor to abolish or abandon the system may have real merit. ${ }^{16}$

These comprehensive and reliable statistics which are necessary for determining whether the bail system actually provides any useful services to the state are not presently available. Consequently, no one really knows how well the professional bail bondsman system is working. ${ }^{17}$ It may be useful, nonetheless, to examine what is currently known about the California bail system to locate those places where reforms are necessary.

The first portion of this Comment describes the California pretrial release system, and analyzes the bail system from the respective points of view of the client, the bondsman, and the state regulatory agency. ${ }^{18}$ The second portion evaluates, on the basis of preliminary field studies, the effectiveness of the present system in terms of getting defendants out of jail and back to court for their trials, and discusses some of the structural and administrative problems of the bail system. The third section proposes specific solutions to these problems, and the last section briefly describes the alternatives to the bail system adopted by the State of lllinois and by the federal government. The conclusion suggests that with the incorporation of these proposed reforms, the present California bail system merits retention pending further detailed studies of its value.

\footnotetext{
${ }^{15} \mathrm{~A}$ remission is the act by which a forfeiture is forgiven. See text accompanying notes $63-81$ infra for further discussion of California remission procedures.

${ }^{16}$ See, e.g., materials cited at note 4 supra. Inaccurate, inadequate, or completely unavailable statistical information on the operation of the bail system is not a unique California problem. See, e.g., Kamin, Bail Administration IN Illinols, 53 lll. B.J. 674, 681 (1965) Thereinafter cited as Kamin]; McCarthy \& Wald, The District of Columbia Bail Project: An Illustration of Experimentation and a Brief for Change, 53 GEO. L.J. 675, 685-86 (1965) [hereinafter cited as McCarthy \& Wald].

"The facilities for obtaining these statistics exist-the legislature, the California Judicial Council, and the California Insurance Commissioner need only manifest their interest in putting the available machinery to work on the problem. See text accompanying notes 175-80 infra.

${ }^{13}$ Interviews with judges, attorneys, public officials, bondsmen, and defendants provided most of the information and observations for the Comment.
} 


\section{CALIFORNIA PRETRIAL RELEASE PROCEDURES}

The California Penal Code provides four pretrial release procedures: bail, release on own recognizance (OR), stationhouse release, and citation in lieu of arrest. Bail is the most widely used method of securing pretrial release. ${ }^{19}$

\section{A. Release on Bail}

\section{From the Client's Point of View}

Historically, bail involved the delivery of an accused from the custody of the sheriff to the custody of a personal surety, who agreed to surrender himself to the court in the event his prisoner escaped..$^{20}$ As the system developed, the sureties were allowed to forfeit a specified sum of money instead of themselves;21 today the bail system relies upon a security of money instead of men. ${ }^{22}$ The professional bondsman appeared early in American history to supplement the private surety. ${ }^{23}$

${ }^{19}$ See text accompanying notes 111-19 infra.

${ }^{20}$ FREED \& WALD, supra note 4 , at 1 . The word "bail" is derived from the Old French verb baille meaning to deliver, or from the Old French noun bail meaning a guardian, keeper, or jailer. In modern usage, it generally pertains to a situation in which one person holds something or someone for another. As a verb, "to bail" means to grant liberty to a person under arrest or to provide the guaranties on which he is released. Used as a noun, "bail" means either the seeurity given for pretrial release or the person who files the guaranty with the court. GoldFARB, supra note 4, at 6 . See Comment, Bail and the Indigent: Is There Equal Justice under the Law?, 9 ST. L.U.L.J. 268, 269 (1964); Sweet, supra note 4, at 26 n.l. A bail bond is a contract running to the state from the defendant as principal with his bail as surety. $C_{A L}$. INS. CODE $\S 1800.4$ (West 1955). The consideration for this contract is the defendant's release froin jail. People v. McReynolds, 102 Cal. 308, 311,36 P. 590, 591 (1894). See Hayes, supra note 4, at 387; Note, Indeminification Contracts in the Law of Bail, 35 VA. L. Rev. 496 (1949) [hereinafter cited as Note, Indeminification Contracts].

The form of bail bond used in California is specified by CAL. PEN. CODE $\$ \$ 1278,1287,1316$ (West 1956). See generally Gustafson, Bail in California, 44 CALIF. L. REv. 815 (1956) [hereinafter cited as Gustafson]; CAL. Civ. CODE $\$ 2780$ (West 1954).

Although there are technical differences between a bail bond and a recognizance, in common usage the terms are practically interchangeable. A bail bond is a contractual obligation signed by the principal and his surety. A recognizance is a formal obligation of record entered into before the court; it necd not be signed by either the principal or his surety. See generally Murphy, State Control of the Operation of Professional Bail Bondsmen, 36 U. CINN. L. REv. 375, 410-12 (1967) [hereinafter cited as Murphy]; Sullivan, Proposed Rule 46 and the Right to Bail, 31 Geo. WAsH. L. REv. 919, 926 (1963) [hereinafter cited as Sullivan]. There are also technical differences between a bail bond, which a nonprofessional surety or bail permittee posts with his own money, and an undertaking of bail, which is posted by a professional surety corporation. The purpose and effect of both obligations are similar.

"See Comment, Bail: The Need for Reconsideration, 59 Nw. U. L. REv. 678 n.l. (1964).

${ }^{22}$ Longsdorf, Is Bail a Rich Man's Privilege?, 7 F.R.D. 309, 310 (1947) (hereinafter cited as Longsdorf]; Sullivan, supra note 20, at 923.

${ }^{23}$ FREED \& WALD, supra note 4, at 3. 
A defendant in a criminal trial is entitled to be released on bail as a matter of right except for a capital offense when the proof or presumption of guilt is great. ${ }^{24}$ Section 1271 of the California Penal Code provides that the defendant who is not charged with a capital offense has a right to release on bail prior to conviction..$^{25}$ Upon appeal, bail is a matter of right when the judgment imposes only a fine, or a period of imprisonment on a misdemeanor charge; in all other cases, release on bail pending appeal is a matter of the court's discretion. ${ }^{26}$

In fixing the amount of bail, Penal Code section 1275 requires the magistrate to consider the seriousness of the offense charged, the defendant's previous criminal record, and the probability of his appearing at the trial. ${ }^{27}$ However, to accelerate the pretrial release process, the municipal and justice court judges in each county adopt a bail schedule for all misdemeanor offenses. ${ }^{28}$ The misdemeanor defendant need not appear personally before a magistrate; he may secure his release by posting with either the officer in charge of the jail or the clerk of the court having jurisdiction over him the amount specified in the schedule for the offense charged. ${ }^{29}$

A further provision requires the magistrate to fix a suitable amount of bail on each arrest warrant, taking into account the same factors specified in section 1275 of the Penal Code. ${ }^{30}$ This leaves only those defendants arrested without a warrant and charged with an offense not provided for on a bail schedule-a felony-who must appear before a magistrate before securing release on bail. Most arrestees who arrange for bail do so through a bondsman. The Penal Code specifically grants every arrestee the right to telephone a bondsman within three hours of his arrest. ${ }^{31}$

The premium for a commercial bail bond in California is generally ten percent of the bond's face value. ${ }^{32}$ Commercial surety bonds are good

${ }^{24}$ CAL. CONST. art. $1, \S 6$.

${ }^{29}$ CAL. Pen. Code $\$ 1271$ (West 1956).

${ }^{26} / d$. $\$ 1272$.

"CAL. Pen. CODE $§ 1275$ (West 1956).

${ }^{23} / d . \S 1269 \mathrm{~b}$. The clerk of the municipal court should be available 24 hours a day, seven days a week, to accept bail. CAL. Gov. CoDE $\S 72301$ (West 1964).

${ }^{29} \mathrm{~A}$ magistrate may set a higher bail than that specified in the bail schedule for the particular offense charged. Wadey v. Justice Court, 176 Cal. App. 2d 426, 428, I Cal. Rptr. 382, 384 (1959).

${ }^{30}$ Cal. Pen. Code $\S 815 a$ (West 1956).

"Id. $\S 851.5$ (West 1967).

32Interview with Wally Perry, a bail bondsman, in Palo Alto, California, August 1, 1967 (on file with the California Law Review) [hereinafter cited as Perry interview]; interview with Michael Annibale, General Agent for National Auto \& Casualty Co., in San Francisco, August 14, 1967 (on file with the California Law Review) [hereinafter cited as Annibale interview]; Brodie, Bail in California, supra note 9, at 2I. For a brief description of the bail bond business in California, see 
for one year. ${ }^{33}$ If the defendant does not come to trial before the bond expires, he may have to pay an additional premium each year in advance. He does not get a pro rata refund if he does come to trial and the surety is released from liability before the bond expires. ${ }^{34}$

Commercial bail bonds are not the only type of bail. The defendant may post a noncommercial bail bond which theoretically costs him nothing. ${ }^{35}$ However, the statute further specifically states that the surety on these noncommercial bonds may not receive payment from anyone, either directly or indirectly, for furnishing the bond. ${ }^{36}$ Therefore, the defendant may find it quite difficult to find anyone qualified to act as a surety who will assume the risk.

Professional bondsmen do not automatically bail out every defendant who can pay the premium for a bond. On the other hand, many bondsmen will give credit to a reliable defendant who is unable to pay the full amount of the premium at short- notice. ${ }^{37}$ The professional bondsman's decision to post bail for a given defendant is largely subjective. ${ }^{38}$ The primary indicator of a successful prospect for pretrial release is the defendant's ties with the community which will deter him from fleeing. ${ }^{39}$ Tangible proof of a probably successful prospect, to the bondsman, is the willingness or ability of the defendant, his family, or his friends to put up the collateral security which the bondsman can sell in order to recoup his losses in the event of a bail forfeiture. ${ }^{40}$

The guarantor who puts up collateral incurs several liabilities. A typical bail agreement contract between the surety company and the guarantor provides that the guarantor will pay the surety the full a-

United States Fid. \& Guar. Co. v. State Board of Equal., 47 Cal. 2d 384, 386, 303 Y.2d 1034, 1035 (1956). Sections $2081-82$ of the California Administrative Code (1953) specify what charges the bondsman may collect.

If the bondsman holds a bail permittee's license which permits him to put up his own money on the bond, he may charge whatever rate he has filed with the Insurance Commissioner. Id. $\$ 2094$.

${ }^{33}$ Interview with William Berti, bail bondsman, in San Jose, August 3, 1967 (on file with the California Law Review) [hereinafter cited as Berti interview].

${ }^{4}$ See, e.g., Bail Agreement form RI-131, Rev. 9-62, of the Resolute Insurance Company (on file with the California Law Review) Thereinafter cited as the Resolute Bail Agreement].

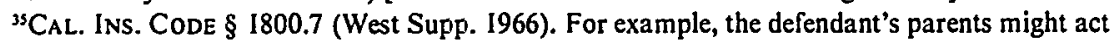
as surety on the bond, if this is acceptable to the court.

${ }^{36} / d$.

${ }^{37}$ See FREED \& WALD, supra note 4, at 24-25.

${ }^{3 *}$ Perry interview, supra note 32 . By way of contrast, many OR release projects usc a mechanical point system. See text accompanying notes $97-99$ infra.

${ }^{39}$ See GOLDFARB, supra note 4, at 156-60.

${ }^{10}$ See Botein, The Manhattan Bail Project : Its Impact on Criminology and the Criminal Law Process, 43 TEXAS L. Rev. 319, 322-23 (1965). 
mount of the bail bond immediately upon its forfeiture. ${ }^{41}$ The guarantor is also liable up to the full amount of the bail bond for the actual expenses which the surety incurs in securing the defendant's release and in recapturing him, if necessary, and if a bail forfeiture is not set aside, the guarantor's liability may extend to the expenses incurred in the attempted recapture in addition to the amount of the forfeiture.42 Finally, the surety may require the guarantor to pay as collateral upon demand the full amount of the bail bond whenever the surety deems such payment necessary for his self-protection, due to any material change in the risk he has assumed. ${ }^{43}$ The recording of the bail agreement constitutes a lien on the specified property of the guarantor in favor of the surety until the surety's liability has been completely exonerated..$^{44}$

Complete insulation of the surety company by virtue of the guarantor's indemnification agreement from the economic consequences of a bail forfeiture would produce little or no incentive for the surety to attempt to recapture the fugitive defendant. However, complete indemnification is seldom achieved. If the surety required one hundred percent collateral, many of the bondsman's clients could not secure release on bail, and the bondsman's income would decline. Therefore, since the bondsman actually bears the risk of loss in the event of forfeiture, he exercises discretionary power in setting collateral requirements on a client by client basis. ${ }^{45}$

\section{From the Bondsman's Viewpoint}

The structure of the California bail bond business is like a pyramid. The insurance companies whose names appear on the surety bonds are at

"Resolute Bail Agreement, supra note 34; CAL. AdmIN. Code tit. 10, § 2081 (1953).

For many years, indemnification contracts between the bondsman and guarantors for the defendant were held void and unenforceable as against public policy, since these agreements tended to reduce the bondsman's personal interest in having his client appear on schedule. See E. ARNOLD, Outlines of Suretyship and Guaranty § 71, at 106 (1927); A. Stearns, The Law of SURETYShIP 437, 509 (5th ed. J. Elder 1951). This is still the rule today in England. S. RowlatT, The Law of Principal and Surety 204 (3d ed. A. Mocatta 1936); Note, Indemnification Contracts, supra note 20 , at 498.

However, in 1912 the United States Supreme Court decided that contracts with the principal or guarantors to indemnify the surety were enforceable. The Court held that even without such an indemnification contract, the surety's interest in producing the body of the defendant in court was already impersonal and wholly pecuniary. Leary v. United States, 224 U.S. 567, 575 (1912).

${ }^{42}$ Resolute Bail Agreement, supra note 34.

${ }^{43} / d$.

4Id.

4sweet, supra note 4, at 13; FREED \& WALD, supra note 4, at 27. See Brodie, Bail in California, supra note 9 , at 22 , for the argument that collateral deposits and signatures of guarantors in misdemeanor bail cases are normally required more as a psychological deterrent to flight than as a protection against loss. 
the apex, the producers who actually write the bonds in their capacity as agents for the surety companies are at the base, and several layers of general agents lie in between. ${ }^{46}$

Every insurance company licensed to issue surety bonds in California may engage in the bail bond business. ${ }^{47}$ Although the bondsman bears the risk of loss on any bond, the key man in the bail bond business is the general agent, the wholesaler in the system. ${ }^{48} \mathrm{He}$ may act in place of the surety company in transacting its business; he selects the bondsmen who may write bonds for the company; he provides administrative materials and advice to the bondsman; and he bears the risk of loss in the event the bondsman becomes insolvent and the surety has to pay off on a forfeited bond. ${ }^{49}$

Section 1279 of the Penal Code specifies the qualifications of a sufficient surety. ${ }^{50} \mathrm{~A}$ California resident with assets exceeding the amount specified in the bond (excluding those assets exempt from execution) meets these qualifications.' The surety must file an affidavit with the court stating that he fulfills the statutory requirements, and provide information on the number of bail bonds he has posted in the past year and the amount of liability on all his outstanding bonds. ${ }^{31}$

As of July 1967, there were approximately 900 licensed bail bondsmen qualified to transact business in California. ${ }^{52}$ There are three

${ }^{46}$ See Sweet, supra note 4, at 12-13.

"See Perry interview, supra note 32.

"Annibale interview, supra note 32.

${ }^{4}$ If the bondsman posts a $\$ 1000$ bond, the client pays a premium of $10 \%$, or $\$ 100$. The bondsman keeps $\$ 73$ as his commission, and deposits an additional $\$ 10$ in his security reserve account with the surety company. Of the remaining $\$ 17$ of the premium, $\$ 15$ goes to the general agent and $\$ 2$ goes to the bonding company. The bondsman keeps such a large percentage of the bond premium because, unlike an ordinary insurance agent, the bondsman pays out first in the event of loss. The general agent guarantees to repay any loss suffered by the surety company, in the event the bondsman's reserve account is inadequate to cover the forfeiture. The general agent will be reimbursed for his losses by the bondsman out of future earnings. See Groves v. City of Los Angeles, 246 P.2d 976, 977 (1952), vacated, 40 Cal. 2d 751, 256 P.2d 309 (1953): "Duc to the peculiar and hazardous nature of the bail bond business, the practice has grown up of requiring general agents and subagents to guarantee the undertakings of the insured, fortified by a deposit of collateral." Some bondsmen fecl they should organize their own surety company and keep a larger slice of the premium pie. Perry interview, supra note 32.

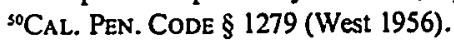

${ }^{3} I d$. $\S \S 1280-1280$ (a).

${ }^{32}$ Interview with Mrs. May Leong, Chief Clerk, License Bureau, California Department of Insurance, in San Francisco, August 25, 1967 (on file with the California Law Review) (hereinafter cited as Leong intervicw]. See also California Department of Insurance form 437-14 (8-67) 150, a list of licensed bail bondsmen prepared for county clerks eaeh month by the Department of Insurance. Available upon request from California Department of Insurance. 
three types of bail bondsmen in California::53 bail permittees who put up their own money on bail bonds; bail agents who post bonds for surety companies; and bail solicitors who are employees of bail agents. ${ }^{54}$ Almost half of the bondsmen are Negro; roughly 15 percent are women. ${ }^{5 s}$

According to the statutory form of the bail bond, the sureties on the bond undertake the obligation that the defendant will appear in court to answer the charge or indictment, that he will at all times hold himself amenable to the orders and process of the court, and that if convicted he will appear for pronouncement of judgment or grant of probation. ${ }^{56}$ if the defendant fails to perform these conditions, the sureties agree to pay the penal amount of the bond to the state, and consent to the entry of a summary judgment against them. ${ }^{57}$

The defendant who posts bail through a bondsman is released to the bondsman's custody..$^{58}$ The bondsman, however, generally has only a minimal custodial relationship with his client. In practice, most bondsmen do not see their clients again once the premium is paid. ${ }^{59}$ ln view of the large number of clients they deal with each year ${ }^{60}$ and the knowledge that most clients will appear in court on schedule without prodding, bondsmen generally make little or no effort even to maintain

\footnotetext{
s'CAL. INS. Code $\S$ I801 (West 1955); Insurance Commissioner of the State of California, Application for Bail License, form 43I-1 (3-65) 5 (1965) (on file with the California Law Review) [hereinafter cited as Bail License Application form]; Leong interview, supra note 52.

${ }^{s 4}$ In July 1967 there were about 40 bail permittees, 750 bail agents, and 160 bail solicitors licensed in California. See form 437-14, supra note 52. These figures add up to 950, but all of the bail permittees are also licensed as bail agents. Perry interview, supra note 32 .

${ }^{35}$ Leong interview, supra note 52; interview with Robert Donnachie, Investigator with the California Department of Insurance, in San Francisco, August 29, 1967 (on file with the California Law Review) [hereinafter cited as Donnachie interview]. These are merely estimates; the Department of Insurance does not classify bail licensees by raeial or sex categories.

${ }^{36}$ CaL. Pen. Code $\S \S 1278,1287$ (West Supp. 1967).

${ }^{57}$ See, e.g., People v. National Auto \& Cas. Co., 242 Cal. App. 2d I50, 51 Cal. Rptr. 2 I2 (I966). "Since the judgment against the bail is one taken by consent, the obligation assumed is absolute but for the defenses set forth in $\S$ I305, and these must be asserted within the 90 day period or the court loses jurisdiction." Id. at 153,5 I Cal. Rptr. at 214 . Section 1305 has subsequcntly been amended to provide for a 180 day remission period. Ch. 1926, [1964-65] Cal. Stats. 4448.

s'See E. Lunt, Surety Bonds: Nature, Functions, Underwriting Requirements $\$$ I17, at 160 (1930); See also Desmond, Bail-Ancient and Modern, 1 Buff. L. REv. 245, 248 (1952).

${ }^{59}$ See Lunt, supra note 58, § 117, at 160: "The principal goes withersoever he listeth as soon as - the bond is issued, so far as the surety company is concerned, and the latter forgets him completely unless and until it is unpleasantly reminded of him by a forfeiture of a bond;" Foote, Introduction: The Comparative Study of Conditional Release, 108 U. PA. L. REv. 290, 300 (1960); Sullivan, supra note 20, at 928 n.51, 935; Note, Bail-Obligation of a Bail, 13 U. PitT. L. Rev. 755, 755-56 (1952).

${ }^{60}$ Estimates range from one to more than two thousand clients annually. Berti interview, supra note 33; Perry interview, supra note 32.
} 
contact with their clients in the pretrial period, let alone exercise any custodial supervision.

The bondsman is free at any time before the bond's forfeiture to secure the exoneration of the bond by surrendering the defendant to the custody of the officer who would otherwise be in charge of him, but for his release on bail. ${ }^{61}$ If the bondsman can show that there was good cause for the surrender, such as an increase in the risk of default, he need not return the premium..$^{62}$ The bondsman may arrest his client for the purpose of making a surrender.

Since the bondsmen generally do nothing until their clients fail to appear, the principal service which the bondsman performs for the state is retrieving fugitive clients. The bail forfeiture and remission process is the engine and governor of the bail bond release machine; the forfeiture is the stick and the possibility of a remission is the carrot which stimulates the professional bail bondsman to find and to return fugitive clients.

Penal Code section 1305 is the basic statute governing bail forfeiture in California. ${ }^{63}$ It provides in part that if the defendant neglects to appear, without sufficient excuse, for arraignment, trial, or judgment, or upon any other occasion when his presence is lawfully required, or fails to surrender himself in execution of the judgment, the court having jurisdiction must direct the entry of the failure to appear upon its minutes and thereupon declare the forfeiture of the undertaking of bail or the money deposited in lieu of bail. Formal entry in the minutes of the failure to appear is the important step, since the running of the 180 day remission period begins at that point. ${ }^{64}$

The remission period is of fundamental importance to the California bail system's successful operation. When a defendant fails to appear and the court orders the bond forfeited, the state's primary interest is to secure the defendant's prompt return, not to obtain a financial penalty against the surety. ${ }^{65}$ Therefore, the bondsman has 180

${ }^{61}$ Cal. Pen. Code $\S 1300$ (West 1956).

${ }^{62}$ CAl. Admin. Code tit. 10, $\$ 2090$ (1953).

${ }^{63}$ CAL. Pen. CODE $\S 1305$ (West Supp. 1967). These procedures do not apply to bail forfeitures made pursuant to Cal. Vehicle Code $\S 40512$. Cal. Pen. Code $\$ 1306.1$ (West Supp. 1966).

${ }_{6}^{6}$ People v. Black, 55 Cal. 2d 275, 278, 385 P.2d 915, 917, 10 Cal. Rptr. 459, 461 (1961). See generally Pacific Indem. Co. v. Superior Court, 102 Cal. App. 566, 570, 283 P. 345, 347 (1929) (the docket itself constitutes the minutes of the municipal court). When the misdemeanor defendant exercises his right to appear at trial by counsel, he has not neglected to appear, and therefore the court has no authority to order the forfeiture of the bail. People v. Ross, 221 Cal. App. 2d 443, 447, 34 Cal. Rptr. 505, 508 (1963).

${ }^{65}$ See, e.g., People v. Wilcox, 53 Cal. 2d 651, 656-57, 349 P.2d 522, 525, 2 Cal. Rptr. 754, 757 (1960); Seaboard Sur. Corp. v. Municipal Court, 208 Cal. 596, 598-99, 283 P. 289, 290 (1929) 
days within which either to locate the fugitive and return him to court or to present a satisfactory excuse for his failure to appear. ${ }^{66}$

Section 1305 sets forth three alternative procedures for securing the remission of a bail forfeiture: (1) appearance and excuse or proof of nonconnivance; (2) nonappearance and excuse; (3) appearance and surrender. The first permits the bondsman and the defendant to appear in court within 180 days of entry in the minutes of the defendant's failure to appear, ${ }^{67}$ and satisfactorily excuse the defendant's neglect or show to

(dissent) (it is self-evident that the purpose of bail is to insure the presence of the defendant when required and that the public interest is better subserved by having a fugitive or absconding defendant returned to the court to meet the requirements of justice than by swelling the public coffers with forfeited bail money); People v. Calvert, 129 Cal. App. 2d 693, 698, 277 P.2d 834, 838 (1954); People v. Love, 19 Cal. 676, 682 (1862).

${ }^{66}$ It is provided further than if the amount of the forfeiture exceeds $\$ 50$, the clerk of the court shall promptly mail notice of the forfeiture to the surety on the bond or to the depositor of the money after entering the fact of the defendant's failure to appear in the records. When the forfeited bond is posted by a corporate surety insurer, the clerk shall notify both the surety and the agent or solicitor who posted the bonds. See CAL. PEN. CODE $§ 1305$ (West Supp. 1967). If the clerk fails either to mail promptly such a notice or to post a copy of the order of forfeiture, the surety or depositor shall be released from all obligations under the bond. To post a copy of the order of forfeiture means either to publish the order in a public newspaper of general circulation, place the notice on a public bulletin board in the courthouse, or place the notice in a forfeiture book in the clerk's office which the bondsmen may inspect daily. Occasionally a clerk will inadvertently fail to comply with the sending of the notice provision, necessitating the setting aside of the forfeiture. Interview with Wilbur Johnson, Deputy District Attorney, San Mateo County, in Redwood City, California, July 11, 1967 (on file with the California Law Review). But see Peoplev. Smith, 234 Cal. App. 2d 404, 407, 44 Cal. Rptr. 430, 432 (1965) (clerk's failure to notify surety of forfeiture did not toll the running of the remission period, nor deprive the court of jurisdiction to enter the final forfeiture).

${ }^{67 "[O}[\mathrm{O}] \mathrm{r}$, if mailing of notice of forfeiture is required, within 180 days after mailing such notice of forfeiture...." CAL. PEN. CODE $\S$ I305 (West Supp. 1967). Prior to 1965, the bondsman had only a 90 day remission period within which to return the fugitive. The extended remission period seemingly increases the chances of the bondsman finding and returning his fugitive clients and therefore furthers his incentive to retrieve them in order to avoid a final judgment on the forfeiture. However, a general agent for a surety company complained to the author that the extended remission period makes the bondsmen complacent and lazy and apparently has not reduced the number of forfeitures going to final judgment. Annibale interview, supra note 32.

One observer commented that many of the bondsman's clients are continually in trouble with the law. If one of these clients becomes a fugitive, his rearrest within six months for some new offense is a virtual certainty. Therefore, the bondsman normally can locate these fugitives with a minimum of effort. Interview with Herbert Kutchins, director of the San Francisco Bail Project, in San Francisco, August 29, 1967 (on file with the California Law Review) [hereinafter cited as Kutchins interview]. If a significant portion of remissions result from bondsmen recapturing fugitive clients between the $91 \mathrm{st}$ and 180th day of the remission period there clearly is some justification for retaining the extended period. However, if most of these incremental remissions result from the arrest of the fugitive on a new charge, where the bondsman has performed no service to the state, the utility of the extended period is questionable. The comprehensive bail statistics to be collected by the Insurance Commissioner and the California Judicial Council should aid the legislature in determining whether the extended remission period actually improves the retrieval process. 
the court's satisfaction that the bondsman did not connive in the defendant's absence. Upon compliance with the requirements of this procedure, the court shall discharge the bond forfeiture. But it need not remit all of the bond; it may provide such terms as it deems just. ${ }^{68}$

The statute does not provide guidelines for determining whether the defendant's excuse for neglecting to appear is satisfactory; it leaves this determination to the court's sound discretion. Clearly, a satisfactory excuse would include the common law defenses for a failure to appear, namely: an act of God, an act of the obligee, and an act of law. ${ }^{69}$

The appearance and excuse remission procedures require that both the defendant and his bail appear in court. As long as they have appeared and moved for a remission of the forfeiture within the remission period, the actual remission may come after the 180 day period has expired. See People v. Wilcox, 53 Cal. 2d 651, 657, 349 P.2d 522, 525-26, 2 Cal. Rptr. 754, 757-58 (1960), holding that $\S 1306$ cannot be construed to require a summary judgment when the court has pending before it an application for relief under $\S 1305$ at the end of the [180] day period. As the relief sought in the present case was commenced within the statutory period, the court did not lose jurisdiction to grant that relief and to set aside the forfeiture; Leach v. Dinsmore, 22 Cal. App. 2d 735, 740, 65 P.2d 1364, 1367, (1937), holding that $\$ 1305$ requires only that the appearance and showing be made or possibly only commeneed within the [180] day period.

61"Just terms" may very well include the forfeiture of all but a token amount of the bond. See e.g., People v. United Bonding Co., 240 Cal. App. 2d 124, 49 Cal. Rptr. 360 (1966).

${ }^{69} \mathrm{At}$ common law, an act of God in relation to bail forfeitures included any unforeseeable misfortune beyond human control which rendered the performance of the bond conditions virtually impossible, such as death, insanity, or sickness in the family. Modern courts now seem to be content with "reasonable impossibility" as an excuse-i.e., such a force of nature as will render compliance with the bond sufficiently hazardous to human life to warrant the breaeh. See, e.g.. People v. Calvert, 129 Cal. App. 2d 693, 277 P.2d 834 (1954) (defendant confined to bed with strangulated hernia; held-failure to appear was excusable).

An act of the obligee at common law was an act of the state in which the forfeiture took place, such as an arrest. An act of law which excusably prevented performance of the bonded obligation, such as a statute preventing the bondsman from recapturing a fugitive client, was one that under the orthodox conception had to operate within the bonding state. The minority view extends the term to include the official aet of any state. See 10 OP. CAL. ATT'Y GEN. 212, 213 (1947) (California follows the minority position); Note, Bail: Developments in the Area of Forfeiture and Remission, 40 Notre Dame Law. 455,460 (1965); Note, Relief From Forfeiture of Bail in Criminal Cases, 8 WYo. L.J. 151, 154 (1954).

For a discussion of the consequences of incarceration in another state upon the bail's obligation, see Note, Bail-What Constitutes the Liabillty of the Surety on His Bail Bonds, 18 Boston U.L.Rev. 142, 144-48 (1938). See aiso General Cas. Co. v. Justice Court, 4 I Cal. App. $2 \mathrm{~d} 784,790,107$ P.2d 663, 666 (1940), holding that where the performance of a condition is rendered impossible by either an act of the obligee or of the law, the surety is no longer liable; County of Los Angeles v. Stuyvesant 1ns. Co., 227 Cal. App. 2d 428, 433, 38 Cal. Rptr. 713, 715 (1964).

The appellate courts consider seven factors in passing upon the question of whether the trial court abused its discretion in granting or denying remission of a bail forfeiture:

(1) the facts of the individual case;

(2) the purpose of bail;

(3) the cause and purpose of defendant's nonappearanee;

(4) the good faith of the surety;

(5) the willfullness of the default; 
In the absence of a satisfactory excuse for the defendant's neglecting to appear, the bondsman may still obtain a remission under the first procedure if he can satisfy the court that the defendant's absence was without his connivance. However, the statute does not specify what constitutes satisfactory evidence of nonconnivance. Some judges will presume nonconnivance unless shown facts to the contrary, since the bondsman will lose money if the defendant fails to appear..$^{70}$ Other judges are not satisfied with a mere conclusory statement in the bondsman's affidavit to the effect that the absence of the defendant was without the connivance of the bail, and require specific facts to support this allegation."

The second remission procedure which section 1305 provides is nonappearance and excuse. If within 180 days after the entry of the fact of the defendant's absence in the minutes of the court, the court is satisfied that the defendant is dead or is physically unable, by reason of illness, insanity, or detention by civil or military authorities, to appear in court at any time during the 180 day remission period, and that the defendant's absence was without the bondsman's connivance, the court shall direct the discharge of the forfeiture upon such terms as may be just.

The statute does not specify the point in time at which the satisfactory excuse must exist. ${ }^{72}$ Presumably, a bondsman who locates a

(6) the ability to hold the trial notwithstanding the default;

(7) the need to enforce the penalty of forfeiture as a requirement of public justice. People v. Calvert, 129 Cal. App. 2d 693, 699, 277 P.2d 834, 838 (1954).

${ }^{70}$ Interview with Judge Roy Seagraves, Southern District Municipal Court, San Mateo County, in Redwood City, California, August 24, 1967 (on file with the California Law Review) [hereinafter cited as Seagraves interview].

"Interview with Robert Carey, Chief Criminal Deputy District Attorney, San Mateo County, in Redwood City, California, August 9, 1967 (on file with the California Law Review). See Seaboard Sur. Corp. v. Municipal Court, 208 Cal. 596, 599-600, 283 P. 289, 291 (1929) (dissent). Justice Schenk, dissenting, argued that the word "connivance as applied to one party, in this instance the surety, presupposes some unlawful or wrongful act or omission on the part of another, here the defaulting defendant, that is, some feigned ignorance or acquiescence or encouragement of the surety in the wrongdoing. Connivance is an agreement or consent, directly or indireetly given, that something unlawful shall be done by another." See People v. Meidell, 220 Cal. App. 2d 105, 107, 33 Cal. Rptr. 564, 566 (1963). The court held that $\S 1305$ was not meant to enable a defendant whose bail has been forfeited to come into court and successfully move to set aside the forfeiture solely on the ground that he had not informed his bondsman about his plans to flee, thus eliminating any possibility of connivance with the bondsman. The nonconnivance provision under which relief from forfeiture may be granted was intended to afford relief to a bail who returns an absconding defendant to custody. It should not be available to a defendant who, otherwise, is not entitled to relief because his absence was without excuse. Id.

${ }^{2}$ People v. Durbin, 64 Cal. 2d 474, 477 n.l, 413 P.2d 433, 435 n.l, 50 Cal. Rptr. 657, 659 n.l (1966) (bondsman located defendant in jail in another jurisdiction within the statutory period, and for that reason was unable to bring him into court; remission granted); People v. Rolley, $223 \mathrm{Cal}$. 
fugitive on the 179th day of the remission period may successfully move for a remission if the fugitive is sick or in jail, even if he was not in that condition on the day he failed to appear in court. However, if the bondsman locates the fugitive in a hospital on the 140th day of the remission period and promptly moves to have the bail forfeiture discharged, the court is justified in taking the motion under advisement until the 180 day period has elapsed and then requiring additional proof that the inability to appear in court still exists. ${ }^{73}$ The remission of the forfeiture under this procedure is mandatory, as is the case with the "appearance and excuse" procedure. And here also the court has the power to modify the remission upon "just terms" which may have the effect of penalizing the bondsman and compensating the state for the expense which the delay caused..$^{74}$

The third remission procedure specified in section 1305 gives the bondsman three options. If at any time within the 180 day remission period he appears in court with the defendant in his custody, he may surrender the defendant to the court, move to set aside the forfeiture, or request the court not to reinstate the bond..$^{75}$ The statute imposes only

App. 2d 639, 641, 35 Cal. Rptr. 803, 804 (1963) (remission language should be interpreted as reading "will be unable to appear during the remainder of said [180] days"). Contra, People v. Houle, 153 Cal. App. 2d 894, 897, 316 P.2d 100, 102 (1957) (if the defendant is able to appear in court at any time during the [180] days and does not do so, the court is not justified under $\S 1305$ in setting aside the order forfeiting the bond); Gustafson, supra note 20, at 829-30.

"People v. Durbin, 64 Cal. 2d 474, 477 n.l, 413 P.2d 433, 435 n.l, 50 Cal. Rptr. 657, 659 n.l (1966).

${ }^{74}$ See People v. United Bonding Ins. Co., 240 Cal. App. 2d 124, 126, 49 Cal. Rptr. 360, 362 (1966) (court retained $\$ 2,000$ out of forfeited $\$ 3,850$ bond).

${ }^{75}$ Reinstatement of a bail bond after a forfeiture restores the preexisting relationship between the bondsman, the defendant, and the court. One problem which has arisen in the implementation of these remission procedures is the matter of who may appear in court to satisfy the judge that the relevant conditions have been met. May the bondsman appear alone? Need he appear at all? Must the surety company appear through an attorney at law? One source of confusion and conflicting opinions is the unclear meaning of the term "the bail." Is the bail the bondsman, the surety company, or both? Some courts take the position that only the surety has a right to appear in court to move for the remission of a forfeiture. They refuse to permit the bail bondsman, who is only an attorney in fact for the surety company, to exercise this right of the surety. Interview with Judge Jose DeLarios, Northern District Municipal Court, San Mateo County, in South San Francisco, August 17, 1967 (on file with the California Law Review) [hereinafter cited as DeLarios interview].

This interpretation of the statute is of questionable theoretical validity, and furthermore is of negligible benefit to the court. Moreover, this interpretation imposes a costly burden on the bondsmen, who are forced to hire attorneys at law (who formally represent the surety company) in order to make their pleas for remission. In most cases, this additional cost will be passed on to the guarantors who secure the bail bond. If there is no guarantor on the bond, the bondsman must absorb this expense as an additional cost of doing business. Eventually, this increased cost may be reflected in higher bail premiums, or in a higher cut off level of risks assumed by the bondsman with less than $100 \%$ collateral, or in a calculated decision to let the small fry bail jumpers go. The first two alternatives might have the effect of making it more difficult for the marginal defendant to obtain pretrial release on bail. The third alternative is clearly not in the state's interest, since it 
two conditions upon the bondsman under this remission procedure-he must have the fugitive client in his custody and he must make timely application for remission. The defendant's failure to appear need not be excusable, nor need it have been without the bondsman's connivance. However, in contrast to the other two remission procedures, a grant of remission is discretionary with the court.

Section 1300 of the Penal Code gives the bondsman the right to surrender his client in exoneration of the bond to the officer who had custody of the defendant before he was released on bail. However, the bondsman must exercise this power before the forfeiture of the bond. Therefore, the additional grant of this surrender power under section 1305 which allows the bail to surrender the defendant to the court after a forfeiture is a significant increase in the bondsman's powers.

Section 1305 further authorizes the bondsman to request the court not to reinstate the bond. This language implies that the courts have the power to reinstate the bond without the consent of either the bondsman or the surety. Some judges ${ }^{76}$ and many bondsmen ${ }^{77}$ question the legality or the propriety of this practice. One judge feels that unless the written consent of the agent or the surety company is on file with the court, the judge should not reinstate a forfeited bond. ${ }^{78}$ Once the defendant has forfeited his bond by failing to appear, there has been a breach of the contract between the surety and the client, and the court should not

would impede the rapid apprehension of fugitives. Thus it appears that there is no apparent benefit to the state from an interpretation of "the bail" in $\S 1305$ to mean "the bondsman with a lawyer representing the surety company," other than possibly a larger source of revenue from bail forfeitures. To this point, California courts have held that in matters of bail forfeitures, there should be no suggestion of revenue to the state or county, nor of punishment to the bondsman. People $v$. Wilcox, 53 Cal. 2d 651, 657, 349 P.2d 522, 525, 2 Cal. Rptr. 754, 757 (1960).

This argument is reinforced by the historical meaning of the term "bail." At common law, the bail, among other things, was the person to whom the custody of the defendant was entrusted. Thus $\S 1305$ may use the term "the bail" to mean the person who has custody of the defendant. The function of the surety company in the California bail system is to provide a financially responsible guarantor with whom the court can deal, while the function of the bondsman is to make all the practical arrangements with the defendant and the officers of the jails and courts for the release and return of the defendant. Therefore, it seems reasonable that the legislature may have intended to refer to the bondsman as "the bail." If this historical approach to statutory interpretation is correct, then the bondsman should have the right to appear in court on his own behalf without the need for an attorney to represent the surety company.

${ }^{76}$ Seagraves interview, supra note 70.

"See, e.g., Perry interview, supra note 32; interview with Thelma Hammel, bail bondsman, in Redwood City, California, August 7, 1967 (on file with the California Law Review) [hereinafter cited as Hammel interviewl.

${ }^{35}$ Seagraves interview, supra note 70. 
attempt to create a new contract between them without the consent of the parties. ${ }^{79}$

As a practical matter, if the court reinstates the bond without the bondsman's consent, he is free at any time thereafter to surrender the defendant to the sheriff or other proper official and secure the exoneration of the bond..$^{80}$ Depending upon the circumstances of the original forfeiture-for example, if the failure to appear was due to a willful attempt to escape, rather than to the client's ignorance or good faith mistake-he might well be able to retain the defendant's premium. The fact that there is already one forfeiture on the the bond may indicate a sufficient increase in the risk to justify surrender without returning the premium. $^{81}$

\section{3: State Regulation of the Bail Bond Business}

The California lnsurance Commissioner and the Department of Insurance are responsible for administrative regulation of the California bail bond business. ${ }^{82}$ The Commissioner controls the licensing of bail

"Id. However, by the terms of the standard contract between the surety company and the guarantors, the latter expressly waive notice of default and agree in advance to the reinstatement of any bonds which have been forfeited. See Resolute Bail Agreement, supra note 34.

Much of the time, the bondsman will agree to the reinstatement of the forfeited bond if the circumstances of the forfeiture indicate that the defendant is unlikely to fail to appear again. Berti interview, supra note 33 . Occasionally a judge will assist a bondsman who appears to be making a real effort to locate a fugitive as the remission period nears its close. The judge will helpfully reinstate the bond and then declare it forfeited again, thereby giving the bondsman an additional 180 days to find the defendant. DeLarios interview, supra note 75.

The bail is entitled to have the forfeiture discharged whether or not the fugitive was recaptured by its efforts. People v. United Bonding Ins. Co., 240 Cal. App. 2d 895, 897, 50 Cal. Rptr. 198, 200 (1966). Nevertheless, see Brodie, Bail in California, supra note 9, at 25 for the claim that "more than two-thirds of the failures to appear are pursued, discovered and returned to the processes of the court by the bondsman."

Except for those minor cases where the courts are interested in establishing a record of conviction for subsequent proceedings (for example, in cases involving CAL. VeHICLE CODE \$ 23102-misdemeanor drunk driving) judges will not issue bench warrants for a failure to appear in most misdemeanor cases. Seagraves interview, supra note 70 . This means that the sheriff will not arrest the defendant, which would discharge the forfeiture at public expense. Instead, the judges leave it up to the bondsman to get the defendant to court. Id. See also 1964 Senate Hearlngs, supra note 4, at 129 (testimony of Edward McLaughlin, deputy district attorney in New York: "The bondsmen ... . are much more effective in returning a fugitive than the law enforcement agents"). For an opinion that bondsmen perform their retrieval function "only infrequently," see 1966 Senate Hearings on Fugitive Bailees, supra note 9, at 34-35 (letter from John Price, District Attorney of Sacramento County, California).

${ }^{80}$ Cal. Pen. Code $\$ 1300$ (West 1956).

${ }^{8}$ CAL. ADMIN. CODE tit. 10, $\$ 2090$ (1953) specifies the conditions which must be met before the bondsman can surrender his client without refunding the premium.

${ }^{82}$ In 1937 the legislature adopted the Bail Bond Regulatory Act, Cal. INs. CoDE $\$ \$ 1800-22$ (West Supp. 1967), which provides a comprehensive statutory framework for state supervision of the professional bail bondsman. The Insurance Commissioner is authorized to make reasonable 


\section{bondsmen ${ }^{83}$ and supervises their conduct. ${ }^{84}$ The Department of Insurance}

rules which may be necessary, advisable, or convenient for the administration and enforcement of the Regulatory Act. The current administrative regulations are found in $\$ \S 2053-104$ of the California Administrative Code. Together, the Bail Bond Regulatory Act and the administrative regulations adopted in furtherance thereof provide a comprehensive and fairly effective system of controls over the California bail business.

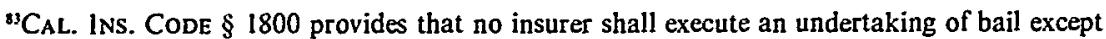
through and by a licensed person, and that no one without a license shall solicit or negotiate for an undertaking of bail by an insurer. The principal purpose of the licensing statute is to protect the public, rather than the surety, from unfit persons. See 21 Op. Cal. ATT'y GEN. 79 (1953).

There are roughly 125 applications for bail licenses filed each year with the Insurance Commissioner. A bail license will not be issued to a person who is regularly or frequently engaged in the administration of justice or associated with a court of law, a public law enforcement agency, an active member of the California State Bar, or an associate of "persons of bad general or bad business reputation or criminals, gamblers or dissolute persons, except to the extent that such association is required in the transaction of bail with such persons." $C_{A L}$. ADMIN. CODE tit. 10, $\$$ 2057 (1953). The license application must indicate the applicant's employment and arrest records. A felony canviction is an automatic bar to approval. Each applicant is investigated by the Department of Insurance, which makes a "neighborhood check of moral character." Less than five percent of license applicants are disqualified at this stage. About six rejected applicants request a hearing each year to contest this deeision.

- The applicant who passes the scrutiny of the Insurance Department investigators gets a temporary license for six months. Within this period, the applicant must pass a written examination. Roughly $80 \%$ of the applicants eventually succeed in becoming bondsmen. With an average of 100 new licenses being issued each year, while an average of only 50 bondsmen decide not to renew their licenses, the ranks of the California bail bondsmen are steadily increasing.

The Insurance Commissioner has the discretionary power to deny a bail license application. McDonough v. Goodcell, 13 Cal. App. 2d 741, 746-47, 91 P.2d 1035, 1039 (1939). The commissioner is authorized to suspend or revoke licenses for violations of the regulations he promulgates, whether or not the licensee has becn first convicted for the violation in a criminal court. Smith v. Downey, 109 Cal. App. 2d 745, 748-49, 241 P.2d 618, 620 (1952).

"According to regulations issued by the Insurance Commissioner, a bail agent or permittee who employs other agents, permittees, or solicitors is supposed to exercise a reasonable degree of supervision over his employees. CAL. ADMIN. CODE tit. 10, $\$ 2063.1$ (1953). The employer's license is subject to suspension or revocation if his employees fail to comply with all laws and rules regulating the bail business. Id. $\S 2063.3$.

Bondsmen may not promote business by encouraging anyone to violate the law, and they may not make arrangements to furnish bail to anyone in advance of the commission of an unlawful offense. Id. $\S 2070$. Attorney referrals and fee splitting arrangements are expressly forbidden. Id. $\S \S$ 2071 , 2072. Bondsmen may not solicit business in prisons, jails, or courts, Id. $\S 2074$, or from anyone other than the arrestee, his attorney, adult members of his immediate family or some other person designated by the arrestee in writing. Id. $\S 2079$. Bail solicitation may only be made after the arrestee or his representative make a legitimate request for bail services. Id. $\S 2079.5$.

Bondsmen must keep accurate records of every bail transaction. Each client gets a written statement containing the material terms of the undertaking (amount of bail, premium charge, itemization of all expenses, total charges, amount reeived on account, and unpaid balance, if any). Id. $\$ 2083$. The bondsman receives collateral in a fiduciary capacity, and it must be returned to the guarantor as soon as the bond is discharged, or as soon as the right to seeure a discharge of liability under the bond accrues. Id. $\S 2088$. The bondsman may not enforce a guarantor's agreement without disclosing all property held by the bondsman pursuant to the particular bond, and the identity of all other guarantors. Id. $\$ 2084$. If real property is received as collateral, the bondsman must exeeute a reeonveyance immediately upon satisfaction of the obligation secured. $I d . \$ 2088.5$. 
devotes 10 percent of its energy to regulating the bail bond business. ${ }^{85}$ Violation of Insurance Code or Administrative Code regulations of the bail business is a public offense punishable by a ten thousand dollar fine or up to 10 years in prison. ${ }^{86}$ Tips from law enforcement agencies, leads uncovered during routine checks, and citizens' complaints activate the investigative machinery of the Department. ${ }^{87}$

\section{B. Alternatives to Bail in California}

\section{Release on Own Recognizance}

A recognizance is an agreement in writing filed with the court in which the defendant agrees to appear at all times and places as the court orders, and to waive extradition if he is apprehended outside of California after failing to appear. ${ }^{88}$ Any defendant eligible for release on bail is also eligible for release on his own recognizance, if in the court's discretion it appears that the defendant will appear as required.89 However, no defendant has a right to release on his own recognizance, ${ }^{90}$ and the statute requires a showing of good cause before the court may order such a release. ${ }^{91}$ After the defendant's OR release, the court may require him to post bail or other security in order to remain free pending trial. ${ }^{92}$ Penal Code section 1319.4 encourages compliance with the promise to appear. by providing that a willful failure to appear on a felony charge constitutes an independent felony offense, ${ }^{93}$ and a willful failure to appear on a misdemeanor is an independent misdemeanor offense. ${ }^{94}$ There is no comparable penalty for jumping bail..$^{95}$

In the event of a forfeiture, the amount of collateral in excess of the amount of the bond forfeited (plus certain allowable expenses) must be returned immediately to the guarantor. Id. $\$ 2089$.

The bondsman must file a copy of each form he intends to use in his business, Id. $\S 2095$, and the Insurance Commissioner has 30 days to inspect it and prohibit its use if it is defective or misleading. Id. $\S 2096$. The bondsman must transact his business upon the forms filed by him with the Commissioner. Id. \$ 2102.

${ }^{\text {ss }}$ Problems of the general insurance industry occupy the major portion of the agency's attention. The department has almost no problems in regulating the activities of the surety companies. Interview with James Feeley, counsel with the California Department of Insurance, in San Francisco, August 25, 1967 (on file with the California Law Review) (hereinafter cited as Feeley interview].

${ }^{86}$ Cal. Pen. Code $§ 1814$ (West 1955); see 8 Op. Cal. Att'y Gen. 190 (1946).

${ }^{87}$ Donnachie interview, supra note 55 .

${ }^{8}$ CAL. PEN. CODE $\$ 1318.4$ (West Supp. 1967).

"Id. $\$ 1318$.

${ }^{9} I d . \$ 1318.2$.

"Id. \$ 1318.

${ }^{92}$ Id. $\$ 1318.6$.

93/d. $\$ 1319.4$.

9II. \$1319.6.

${ }^{\text {"s }}$ Many commentators have urged that bail jumping be made an independent crime. See, e.g., 
California and other jurisdictions have generally had satisfactory experience with the release on own recognizance provisions. ${ }^{96}$ Most jurisdictions have developed systematic procedures for verifying the information which the defendant supplies concerning his ties to the community. The Manhattan Bail Project in New York City originated the use of an objective point system for determining which defendants to recommend to the court for OR release. ${ }^{97}$ Under this system, the OR release applicant receives points for a number of factors indicating stability and ties to the community, such as a steady job, a family in the area, and a relatively clean recent police record. If the defendant obtains a specified point score, the project interviewer recommends that the magistrate act favorably on the defendant's request for OR release. The San Francisco Bail Project also uses this method..$^{98}$ Other courts in California simply want verified information without any recommendations.99

The basic premise of the OR release system is that most defendants who have ties to the community-property, family, employment-are likely to appear in court when their presence is necessary without the need for any artificially created custody relationship with a bail bondsman. Although OR release is not limited to the indigent, in practice a large number of defendants who can afford to pay for a bail bond do so in order to secure immediate release even though they would be virtually certain of eventually obtaining an OR release without cost. ${ }^{100}$ The OR investigative machinery is somewhat ponderous: an investigator must interview each applicant for OR release and then verify the

Foote, Constitutional Crisis in Bail, supra note 2, at 1163. Some jurisdictions do penalize bail jumping with criminal sanctions. See, e.g., committee comments, ILl. ANN. STAT. ch. $38, \S 110$ (Smith-Hurd 1964).

${ }^{96}$ E.g., Hopper, Comparison: Bail-O.R.-A Statistical Report on the San Francisco O.R. Project (1966) (on file with the California Law Review; available upon request from the San Francisco Bail Project, Hall of Justice, San Francisco) [hereinafter cited as S.F. Bail Project Report]. For a report of comparable results with a federal OR project in California, see Scott, Bail Factfinding Project at San Francisco, 30 FED. PROBATION 39 (Dec. 1966). An estimated 98.6\% of the 3,505 persons released during the action phase of the Manhattan Bail Project returned to court when required. 1966 House Hearings, supra note 4, at 41 (testimony of Assistant Attorney General Ramsey Clark). Accord, McCarthy, supra note 14, at 11-12 (comparable results in Washington, D.C. project); Smith, A New Approach to the Bail Practice, 29 Fed. Probation 3, 4 (March 1965) (comparable results in the United States District Court for the Eastern District of Michigan).

${ }^{\text {" }}$ Kutchins interview, supra note 67.

${ }^{93} I d$.

"Interview with Robert Harrison, Executive Director of the Northern California Service League of San Mateo County, in Redwood City, California, August 7, 1967 (on file with the California Law Review).

${ }^{100}$ Kutchins interview, supra note 67. 
information by telephone or a neighborhood visit. The process may take anywhere from one hour to one week or longer to complete. ${ }^{101}$

\section{Stationhouse Release and Citations}

Formally arrested persons are eligible for bail and OR release. California also provides two types of release procedures at an earlier point in the detention process. Under the first procedure, stationhouse release, any peace officer may release a person arrested without a warrant for a misdemeanor rather than take the defendant before a magistrate. ${ }^{102}$ The officer has the defendant sign an agreement to appear in court at a designated time and place. ${ }^{103}$

Under the second procedure, the arresting officer may issue a citation in lieu of a formal arrest for a misdemeanor violation, unless the arrestee demands to be taken before a magistrate. ${ }^{104}$ Under the citation procedure, the arrestee signs a promise to appear before being released. Thereafter a magistrate may set bail which the defendant must post at some point before the trial, under penalty of a second arrest. ${ }^{105} \mathrm{~A}$ willful failure to appear as promised is an independent misdemeanor. ${ }^{106}$ For most Vehicle Code violations, the arresting officer may issue a similar

${ }^{101} I d$.

${ }^{102}$ CAL. Pen. Code $\$ 849(b)(3)$ (West Supp. 1967).

${ }^{103} \mathrm{Id}$. In Alameda County, the district attorney discourages the use of this release procedure, contending that a formal arrest fulfills a valuable screening function. The arrest gives the peace officer a chance to reflect upon his actions away from the scene and to drop weak cases which would otherwise go before a magistrate if a $\$ 849$ (b)(3) release had been used in lieu of formal arrest. Telephone interview with Alameda County deputy district attorney, February 6, 1968.

For a ruling that a $\$ 849(\mathrm{~b})(3)$ release does not change the arrest into a mere detention for reporting purposes, see 43 OP. CAL. ATT'Y GEN. 288 (1964).

${ }^{10}$ CAL. PEN. CODE $\$ \S 853.6-853.8$ (West Supp. 1967).

${ }^{105} I d . \$ 853.6$. Under a discretionary standard, the magistrate normally should not require bail if the defendant has impressed the arresting officer as being sufficiently reliable to merit citation release, unless the magistrate discovers some additional information material to the risk of nonappearance. However, he can require the posting of bail in those cases where forfeiting bail is the accepted procedure for disposing of minor offenses. For example, the 1967 Report of the Judicial Council of California observed tbat "the Uniform Bail Schedule for California . . . provides for the deposit of ten or fifteen dollars for a first offense on most minor traffic violations . . . the practice being that bail in such cases is forfeited without further proceedings. . . . Seventy-three percent of the nonparking traffic filings and more than ninety percent of the parking filings were handled by bail forfeitures in the municipal courts in 1966." JUDICIAL CouNCIL OF CALIFORNIA REPORT 41-42 (1967). See also Waite, Code of Criminal Procedure: The Problem of Bail, 15 A.B.A.J. 71 (1929).

Forfeiture of bail, however, is not a conviction which will bar further prosecution. See Wyatt v. Municipal Court, 242 Cal. App. 2d 845, 849, 51 Cal. Rptr. 862, 865 (1966). In this case, forfeiture of $\$ 50$ bail was intended to be equivalent to fine and punishment for the offense of failing to yield the right of way to a pedestrian in a crosswalk; but when the injured pedestrian died, the defendant was not placed in double jeopardy by subsequent prosecution.

${ }^{106}$ CaL. PEN. Code $\$ 853.7$ (West Supp. 1967). 
citation in lieu of formal arrest. ${ }^{107}$ Again, a subsequent deposit of bail may be required and willful failure to appear is an independent misdemeanor offense. These Vehicle Code provisions are the ancestor of the Penal Code citation release procedure for all other misdemeanors. ${ }^{108}$

One can criticize the citation release process for two reasons. First, there is a lack of definite guidelines for the exercise of police discretion in administering this procedure. ${ }^{109}$ For example, some departments release the arrestee on the street, while other departments bring the arrestee to the police station in order to get a set of fingerprints for identification purposes. This latter procedure would seem to be preferable, unless the arresting officer already knows the arrestee.

The second criticism concerns the limitation of this procedure to misdemeanor arrestees. One commentator contends that the police power to release on citation should extend to both misdemeanor and felony suspects, arguing that "the felony-misdemeanor distinction is not important in determining whether an individual will appear in court or continue to be an immediate harm to himself or the community."110

\section{II}

\section{STRUCTURAL AND ADMINISTRATIVE PROBLEMS OF THE CALIFORNIA PRETRIAL RELEASE SYSTEM}

\section{A. The Victim Test of Effectiveness}

Investigators ${ }^{111}$ have conducted surveys of the bail system in California to evaluate its effectiveness in terms of the percentage of arrestees who were its victims-those unable to secure release within 24 hours because of an inability to meet the monetary conditions of the bail system. The investigators presumably selected the 24 hour period as the test of the effectiveness of the present bail release system for two reasons. First, the surveys were relatively simple to conduct on this basis over an extended period. Second, and more significant, the results which these

${ }^{107}$ CAL. VehicLE Code $§ \S 40500-12$ (West Supp. 1967).

${ }^{108}$ The legislature enacted this citation procedure in 1923. Ch. 26, § 154 [1923] Cal. Stats. 566.

${ }^{109}$ See Note, Alternative to Bail, supra note 6, at 653. For a suggestion that the use of citations would increase if they were limited to minor offenses, excluding crimes of violence, see Brodie, Bail in California, supra note 9 , at 42.

"Note, Alternative to Bail, supra note 6, at 654.

"'Deputy Sheriffs in San Joaquin, Fresno and Kings Counties, reported in California Bondsmen's Bail Testimony, supra note 8, at 9-10, Exhibit F, and student interns with the San Mateo County District Attorney's office. The results of the Deputy Sheriffs' survey are discussed in the text accompanying notes 112-17 infra and the student interns' survey is discussed in the text accompanying notes $118-19$ infra. 
surveys of the bail release system produce could be meaningfully compared to potential results under possible alternative release procedures. For example, the surveys indicate that two out of three arrestees are out of jail within 24 hours after booking. Between 50 percent and 75 percent of those released are released on bail. If some variation of the $O R$ release process replaced the bail system the $O R$ release program's investigation and verification staff would have to process each arrestee now being released on bail. Such an expanded OR release program would require a much larger staff of investigators in order to process as large a proportion of arrestees with the same speed now being achieved under the present system. Whether the benefits achieved by replacing the bail system would justify the greater cost of an increased OR staff is a question for the legislature.

\section{Three County Survey (1964)}

In a three county survey conducted in July 1964 by deputy sheriffs in San Joaquin, Fresno, and Kings Counties, ${ }^{112}$ the county jails booked in 315 arrestees within a 10 day period. Of these arrestees 213 or 68 percent secured release within 24 hours: 113 after posting cash or surety bonds as bail ( 36 percent of the total number booked in, 53 percent of the number released), seven on their own recognizances, and 93 after appearing in court or after charges were dropped. Of the 102 arrestees detained longer than 24 hours, 26 were ineligible for bail, being held on "no bail" warrants or with parole or armed services holds. ${ }^{113}$ Of the remaining 76 held longer than 24 hours, 23 were transients who could not achieve bail; 20 persons "did not want bail" for a variety of reasons; 11417 people had called either a bondsman or a relative or friend but had not secured their release; ${ }^{115}$ and five persons were ignorant of their right to bail or refused to cooperate with the survey. Of the 76 who were eligible for bail but were still in jail after 24 hours, only 11 persons expressly indicated that money was the sole reason for their remaining in jail..$^{116}$

"'California Bondsmen's Bail Testimony, supra note 8, at 9-10, Exhibit F.

${ }^{113} \mathrm{~A}$ "no bail" warrant is simply a warrant where the issuing magistrate has either expressly directed that the defendant not be released on bail or has indirectly produced the same result by failing to designate the amount of bail which the defendant may post to secure his release. Likewise, parole officers and military authorities may request that the defendant not be released on bail before his transfer to their custody.

"The reasons given included: "don't want to spend the money for bail;" "not guilty and believe judge will turn me loose;" "want to get it over with." California Bondsmen's Bail Testimony, stupra note 8, at 10, Exhibit F.

"SThree were turned down by bondsmen; the remaining 14 who called someone other than a bondsman appeared to have been persons who could have qualified for release on bail. Id.

${ }^{116}$ Bail was set at $\$ 3,300$ or more for about half of this group. Id. 
Thus approximately 43 persons (13 percent of the total number of arrestees) remained in jail primarily for financial reasons: 11 expressly for financial reasons, 14 left unhelped by friends or relatives, three turned down by bondsmen, five ignorant of their right to bail and perhaps unable to afford it, and 10 representing those who "did not want bail" probably because they were unable to afford it. Although these last two groups are classified here as victims of the bail system because they were still in jail 24 hours after booking, the system did not necessarily victimize them. That five arrestees were ignorant of their right to release on bail is not the fault of the bail system, but of the jail officials. This problem of ignorance could continue to exist even if some alternative release procedure replaces the bail system. And although the author has classified half of the group of 20 arrestees who "did not want bail" as victims of the system, this estimate of their true reason for not wanting bail may be incorrect. Removing both these groups from the victim category leaves only 28 people, or not quite nine percent of the total number arrested, classified as victims of the bail system. ${ }^{117}$

\section{San Mateo County Survey (1967)}

A similar survey conducted in the San Mateo County jail in August 1967 by two interns with the district attorney's office produced similar results. ${ }^{118}$ In the nine day period which the survey covered, the county jail booked in 201 arrestees. Of this number, 134 or 67 percent secured release from custody within 24 hours: 101 or 50 percent of the total arrested were released on cash or surety bond bail; 17 or eight percent of the total were released on their own recognizances, and 16 were released for a variety of other reasons. Of the one-third of the arrestees still in jail after 24 hours, 33 were sentenced within 24 hours ( 16 percent of the total), 15 or seven percent of the total number of arrestees were ineligible for bail, and 19 or nine percent of the total were either unable or did not choose to post bail.

In this group of 19 persons who were eligible for bail but did not secure release within 24 hours, nine did not want bail; two were transients who had sufficient cash to cover the bail premium but were

"'Another "victim" of the bail system, of course, is the person who pays a bondsman to get out of jail. The fee he pays is an additional penalty for getting arrested. See text accompanying notes $129-$ 31 infra.

I"Bortolazzo \& Hoskins, Survey of Bookings in San Mateo County Jail (1967) (on file with the California Law Review). The daily booking sheets and release slips were reviewed each morning. The interviewers spoke with 10 of the 19 persons who were unable to post bail within 24 hours. The other nine were not interviewed for the following reasons: five were in coun, one spoke on'y Spanish, two were bad risk transients, and one was the defendant in a family rape case where the bail picture was complicated by family problems. 
unable to obtain release either on bail or OR because they lacked community ties-neither the bondsmen nor the OR project investigators were willing to accept the risk; four did not have the money for the bail premium and made little effort to contact friends or relatives to raise the money; and four were attempting to raise bail money. In the judgment of the survey team, only the last eight, or four percent of the total number of arrestees, merit classification as victims of the professional bail bond system, remaining in jail for financial reasons alone.

The data in these two surveys indicate that the present mix of police arrest procedures and pretrial release programs in California produces the release of roughly two out of three arrestees within 24 hours after the completion of the arrest and booking process. ${ }^{119}$ Therefore, the urgent need for reform relates to proccdures for securing the release of the remaining one-third of the arrestees.

Of the total of 169 unreleased arrestees in both surveys who were eligible for release on bail, perhaps only 50 persons merit classification as victims of the present pretrial release system, remaining in jail primarily for financial reasons. This figure includes some arrestees who did not want bail, plus the 15 who had no money, the 21 who had unsuccessfully tried to arrange bail with friends or relatives, and the five who were ignorant of their right to release on bail. Twenty-five arrestees were transients, and 41 were ineligible for release on bail by virtue of the offense charged or the nature of the arrest warrant. The victim category would be larger if the transients and bail-ineligibles are included, and smaller if the definite victims only are included.

\section{B. The Bail Setting Process}

Serious problems arise in implementing the quasi-individualized bail setting process which the Penal Code envisions. ${ }^{120}$ The process tends to result in unfair application of the law to some individuals. The foremost problem is the lack of a systematic procedure for quickly obtaining adequate information about the defendant. ${ }^{21}$ The bail amount which the magistrate selects should be high enough to act as a deterrent

\footnotetext{
"There are two fundamental problems concerning conclusions drawn from these limited surveys. First, the samples represent practices only in county jails in rural and suburban counties. Practices in municipal jails or in urban county jails may differ significantly. Further surveys in thesc areas may substantiate or contradict the results presented here. A second problem with these statistics is that the percentages of both those released and the "victims" may be of limited significance, since there may be substantial distortion produced by using the total number of arrestees without differentiating between felony and misdemeanor defendants. Further surveys should be designed to compensate for these problems.

${ }^{120}$ See text accompanying note 28 supra.

${ }^{12}$ See FREED \& WALD, supra note 4, at 56.
} 
to flight, and yet be within the reach of the defendant so that he may obtain his freedom.122 A second problem is the common practice of resetting bail in a higher amount when the defendant pleads not guilty and requests a jury trial. Although commentators and the California Judicial Council condemn this practice, ${ }^{123}$ trial judges continue to use it to deter the accused from exercising his right to a jury trial in minor cases. $^{124}$

The defendant who is unable or unwilling to meet the bail figure originally set can obtain a rehearing by use of the habeas corpus procedure. ${ }^{125}$ Rather than rely on the initiative of the defendant to stimulate this review process, some critics suggest an automatic review of the bail amount whenever a defendant is unable to secure release within a week or 10 days. ${ }^{126}$ Howevcr, one judge interviewed feels that unless this automatic review procedure were coupled with some information gathering system to give the judge additional facts about the defendant which would in themselves justify lowering the amount, a mere mechanical review would produce little practical benefit. He believes that most judges are quite willing to review their decisions in the light of new information, but are unlikely to reverse themselves without new facts. ${ }^{127}$

\section{The Bail Bondsman's Role in the Administration of Criminal Justice}

In theory and in practice, the professional bail bondsman plays an important role in the administration of criminal justice in California. The theory of pretrial release is quite liberal-as no man is presumed guilty until convicted in a court of law, ${ }^{128}$ no man should suffer unnecessary imprisonment prior to conviction. Therefore, in most criminal cases, the accused has a right to secure his release, subject only

\footnotetext{
${ }^{122} \mathrm{~A}$ possible solution would be to apply the verification techniques of the $O R$ release prograns to the bail setting process. An OR project interviewer verifies the existence of the arrestee's community ties which indicate whether he is likely to flee if released without a bail bond. See Scott, Bail Factfinding Project at San Francisco, 30 Fed. Probation 39, 41 (Dec. 1966).

${ }^{123}$ See 31 Op. CAL. AtT'Y GeN. 175 (1958); Cal. R. Cr. 801.

${ }^{124}$ Seagraves interview, supra note 70.

${ }^{125}$ CAL. PEN. CoDE $\$ \S 1490-91$ (West 1956). The arrestee may also use the writ of habeas corpus to allege illegal confinement and denial of his right to bail. See id. $\S 1473$; Gustafson, Bail in California, supra note 20, at 817-18.

${ }^{126}$ See Brodie, Bail in California, supra note 9, at 4; California Bondsmen's Bail Testimony, supra note 8, at 10-11; Note, Bail in New York, supra note 4, at 716. The Federal District Courts use this type of automatic review. See FED. DIST. CT. R. CRIM. P. 46(h).

${ }^{127}$ DeLarios interview, supra note 75.

${ }^{128}$ But see Smith, Bail Before Trial: Reflections of a Scottish Lawyer, 108 U. PA. L. REv. 305, 309 (1960).
} 
to the condition that he present satisfactory evidence that he is likely to return for his trial. The bail system presumes that the most satisfactory evidence is the promise of a third person either to present the aceused in court or suffer a financial loss. The role of this third person, which is frequently played by a professional bail bondsman, produces two results: It frees the defendant to allow him to prepare his defense and to keep his affairs in order; and it relieves the state of the expense of caring for the accused in jail prior to conviction. The bondsman has the financial ability to get his client out of jail quickly, and he has the expertise in fugitive retrieval to protect his investment.

The bail bondsman, then, is essentially a subcontractor in the state system of administering justice who in theory assumes the state's burden of supervising arrestees. The accused privately bears the direct cost of this service. ${ }^{129}$ The bondsman contends that imposing these costs on the defendant personally rather than on society in general is justified, whether the defendant is innocent or guilty. He argues that since most arrests are prompted by the defendant's suspicious actions, it is not unfair to impose the costs of socially deviant behavior directly on the responsible individual. ${ }^{130}$ However, critics of the bail system argue that no one should have to buy his liberty, ${ }^{131}$ for in a system which puts a price on pretrial freedom, the poor must suffer inecuitable treatment.

The professional bail bondsman's role in the criminal justice system creates two basic problems. The first concerns the bondsman's relationship with his client who obtains pretrial release on bail. The second concerns the defendant who is unable to utilize his right to bail and who therefore must remain in jail pending his trial.

The major problem with the relationship between the bondsman and his client during the pretrial period is that, as a practical matter, there is no relationship, no custody, no supervision. Unless the client is making periodic payments on the premium under some credit arrangement, the bondsman has little reason to maintain contact with him. Very few bondsmen attempt to exercise supervisory control over their clients during the pretrial period. ${ }^{132}$ Thus the supervisory burden which the bondsman supposedly assumes is negligible, and any service he supposedly performs for the state in this area is of questionable value.

\footnotetext{
${ }^{129}$ But see Goldfarb, supra note 4, at 32.

${ }^{130}$ Perry interview, supra note 32. See also Brodie, Bail in California, supra note 9, at 10.

${ }^{13}$ See, e.g., 1964 Senate Hearings, supra note 4, at 162 (testimony of Professor Charles Bowman).

${ }^{132}$ Interview with Don Donaldson, bail bondsman, in San Francisco, August 29, 1967 (on file with the California Law Review).
} 
The bondsman's true reason for existence is the administrative convenience of the criminal law system. He assumes responsibility for his clients, thereby sparing public officials the duty and expense of supervising these defendants' pretrial behavior. If the defendant does not appear when necessary, the officials merely contact the bondsman and rely on him to produce the fugitive or pay the forfeiture. However, since the primary state interest is in prosecuting the defendant rather than collecting a forfeited bail bond, ${ }^{133}$ this delegation of supervision to the bondsman can be justified only if in fact bondsmen adequately perform their retrieval function. And it appears that a significant number of fugitives are located by public officials at public expense, not by bondsmen. ${ }^{134}$ Therefore the courts or some other public agency might well assume the supervisory "nonburden" which bondsmen now carry.

The second area of criticism concerns the bondsmen, the unbailed defendant, and the delegation of discretionary release power to a financially motivated private businessman. ${ }^{135}$ While the factor of administrative convenience which the bondsman provides in relation to the defendant who secures release on bail may be of some benefit to the state, the costs which the present system imposes on those persons who cannot obtain release on bail may more than offset that public gain. If the defendant is poor and cannot produce adequate collateral, the professional bondsman may not bail him out. Or if the defendant is a transient, the professional bondsman usually does not want him as a client. Therefore, for a significant number of defendants, the right to pretrial release is meaningless. ${ }^{136}$ For these unbailed defendants, the period of pretrial detention may have significant deleterious effects on their ability to prepare an adequate defense, their ability to retain their jobs and provide for their families, and their ability to hire adequate legal assistance. Finally, these factors may keep these defendants from presenting themselves as a good risk for probation in the event they are convicted. For these reasons, the probability of conviction and the severity of the sentence which nonbailed defendants receive is greater

${ }^{13}$ See cases cited note 65 supra.

${ }^{134}$ See text accompanying note 67 supra.

i'S See FREED \& WALD, supra note 4, at 27; 1963 ATT'Y GEN's REP., supra note 4, at 67: Fónte. Constitutional Crisis in Bail, supra note 2, at 1159; McCarthy \& Wahl, supra note 16, at 677. But see Brodie, Bail in California, supra note 9, at 14-15, for the practical argument that the bondsman should perform the detailed investigation of the individual defendants which the courts cannot do without creating havoc "by clogging the courts. This reliance upon the professional bondsman is a problem of time and convenience. The arrested person needs an immediate release. The court requires someone upon whom it can rely to assure the appearance of the defendant without the time and effort necessary to make a determination in every case."

${ }^{136}$ See Sullivan, supra note 20 , at 928 n.51. 
than that for defendants released prior to trial. ${ }^{137}$ Crediting the defendant's pretrial detention time against the eventual prison sentence he receives upon conviction would soften the effects of this discrimination.

Whether or not this delegation of state power to the bondsman is effective, it may be improper and unwise, if for no other reason than that it often gives the criminal justice system a very poor public image. From underneath, the system no doubt often looks very much like a racket, resulting in a perhaps justifiably skeptical reaction to the concept of law and order.

\section{Bail Forfeiture Problems}

There are no comprehensive statistics on the number of bail forfeitures, the number of remissions, and the reasons for them in California. There is great need for this information and state agencies could readily obtain it. ${ }^{138}$

${ }^{13}$ See House Comm. on the Judiciary Bail Reform Act of 1966, H.R. ReP. No. 1541, 89th Cong., 2d Sess. 8-9 (1966); 1966 House Hearings, supra note 4, at 16 (testimony of Representative William McCulloch of Ohio); Senate Comm. on the Judiciary, Ball Reform Act of 1965, S. Rep. No. 750, 89th Cong., 1st Sess. 7 (1965); Foote, Bail in Philadelphia, supra note 4, at 1052. For a discussion of the pressures which may induce a defcndant to plead guilty if he is unable to secure pretrial release, see Note, Alternative to Bail, supra note 6, at 652 .

issee text accompanying notes 175-80 infra for a discussion of the statistical compilation role which the state Department of Insurance and the California Judicial Council could perform.

Although the individual bits of information which the independent researcher can uneover are interesting in themselves, they are of questionable significance. For example, one bondsman reported that he had 47 current forfeitures out of roughly one thousand bonds posted in the past six months, for a forfeiture rate of $4.7 \%$. Perry interview, supra note 32 . This same bondsman further estimated that his average loss due to forfeitures going to final judgment was approximately $0.5 \%$, or only five bonds in every thousand. This indicates that roughly eight out of nine forfeitures are set aside for one reason or another before going to final judgment. If the bondsman plays an active role in securing the return of such a high proportion of the defendants who fail to appear, then perhaps he does play a valuable as well as a profitable role in the administration of justice. However, it is not known how many of these defaulting defendants turn themselves in (perhaps through reluetance to cause loss to their friends who put up collateral) or are picked up by the police without any assistance from the bondsman.

A study conducted for the San Francisco bail project examined bail forfeitures in that city for a one month period, and concluded that seven percent of those on bail failed to appear, costing the bondsman roughly $\$ 8,700$. S.F. Bail Project Report, supra note 96 .

A recent study of the Sacramento County Municipal Court conducted by the author indicates that of the 450 bonds totalling more than $\$ 240,000$ posted in a one month period, almost 60 (13\%) were forfeited for failure to appear and two-thirds of these $(9 \%)$ went to final judgment. The value of the bonds originally forfeited was nearly $\$ 30,000$ while the value of the 42 bonds going to final judgment was $\$ 14,600$. This indicates that the one-third of the forfeitures which were set aside accounted for slightly more than one-half of the value of the total forfeitures, which suggests that the bondsmen try harder and are more successful in recapturing the big fish fugitives than the small fry. The average value of the 42 forfeited bonds which went to final judgment was $\$ 350$, while the average value of the 17 bonds which were remitted was $\$ 870$. 
There is sharp debate among participants in the bail system over whether most defendants fail to appear in court due to ignorance and good faith mistake or due to intentional and willful attempts to evade the retributive process of the courts. ${ }^{139}$ One bondsman who holds the latter viewpoint ${ }^{140}$ believes that there are basically two types of bail-jumping defendants: the professional criminals, "who shouldn't be out on bail in the first place"; and the first-time arrestee. The first-timer is ignorant and therefore fearful of what lies ahead. His initial experiences with his own pretrial custody often reinforce his general conception of a prison as a place to be avoided at all costs. 1t is apparently common practice in California jails to house the newly arrested defendants with convicted felons, either because of space limitations or for policy reasons of maximizing security. After gagging on his initial "taste of jail,"141 the first-timer often leaves the table at the earliest opportunity.

\section{E. Recapture of Fugitives}

As an adjunct of the bondsman's surrender power, the bondsman historically has had the power to arrest his client at any time for the purpose of returning him to official custody and exonerating his bond. The bondsman has this power by virtue of his contractual relationship with his client, not by any delegation of authority by the state or the court, ${ }^{142}$ and therefore jurisdictional boundaries do not restrict the exercise of this power. ${ }^{143}$ The "bail piece" is an official document attesting to the existence of the bail relationship between the bondsman and the defendant which the bondsman obtains from the court after his client has fled. Upon presenting this document to the local constabulary wherever the fugitive is located, the bondsman is entitled to their official assistance in the recapture process. ${ }^{144}$ The provisions of extradition laws,

This study suggests that becoming a bail bondsman is not necessarily a way to get rich quick. The premium paid on the 450 bonds posted by the bondsmen in the area would have been about $\$ 24,000$. However, after the cost of forfeitures is deducted, the net income to the bondsmen for the month would be roughly $\$ 9,400$, or $40 \%$ of the total premium. This averages out to approximatcly $\$ 20$ net income per bond.

${ }^{139}$ See Donaldson interview, supra note 132.

${ }^{10}$ Perry interview, súpra note 32.

"This phrase originally appeared in print 15 years ago in Foote, Bail in Philadelphia, supra note 4 , and has subsequently found its way into almost every article written on bail.

${ }^{42}$ See Note, Extra-Jurisdictional Power of a Bail, 66 Dick. L. REv. 101, 105 (1961).

${ }^{4}$ See 1966 Senate Hearings on Fugitive Bailees, supra note 9, at 3-4.

" "See Comment, Bondsmen and the Fugitive Accused-the Need for Formal Removal Procedures, 73 YALE L.J. 1098, 1102 (1964).

One bondsman reported that police in small towns and small cities were generally quite helpful to bondsmen in terms of holding recaptured fugitives in jail while the bondsmen search for other missing clients. However, police in large cities were generally not interested in assisting the bondsmen. Perry interview, supra note 32. 
which apply only to state powers, do not restrict the recapture operations of the bondsman. ${ }^{145}$

Bondsmen can and do delegate their arrest powers. ${ }^{146}$ The person who exercises these delegated powers is known as a "skip tracer." $\mathrm{He}$ operates as a bounty hunter for a commission, usually 10 percent of the value of the bond, plus expenses. ${ }^{147}$ The bondsman may print up handbills with the fugitive's picture and description, and distribute them widely in hopes of picking up tips on the jumper's present location. ${ }^{148}$

California does restrict the cruder free-wheeling activities of bondsmen who attempt to recapture fugitives from other jurisdictions who are found in California. ${ }^{149}$ The bondsman may arrest an out-ofstate fugitive in California only by virtue of a warrant issued by a California magistrate pursuant to an affidavit filed by the bondsman and investigated by the district attorney. ${ }^{150} \mathrm{~A}$ bondsman who takes a fugitive into custody in California by any other process is guilty of a misdemeanor. A serious defect in the present California bail law is that the state encourages or at least condones the use of tactics by California bondsmen operating out of state which it would not tolerate if the bondsman committed them within the state. While California regulatory authorities are not aware of any incidents of physical or psychological abuse of California fugitives recaptured outside the state, ${ }^{151}$ other jurisdictions have reported incidents of such abuse. ${ }^{152}$

\section{1}

\section{SOLUTIONS AND SUGGESTIONS}

One of the major problems in any discussion of the effectiveness of the bail system is the lack of comprehensive and accurate statistics on how well the system functions. Adoption of the proposed remedy to this information gap ${ }^{153}$ may reveal that bondsmen and the bail system do not perform a useful function. Pending the gathering and analysis of such information, however, immediate adoption of the other proposed reforms would improve the present bail system by eliminating some of its inequities and inefficiencies.

${ }^{145}$ See Note, Extra-Jurisdictional Power, supra note 142, at 101.

${ }^{146}$ See Perry interview, supra note 32.

${ }^{147}$ Annibale interview, supra note 32.

${ }^{148}$ Interview with June Cunningham, bail solicitor, in San Francisco, August 29, 1967 (on file with the California Law Review).

${ }^{149}$ CAL. PEN. COdE $\S 847.5$ (West Supp. 1967).

iso Id.

is' Feeley interview, supra note 85.

${ }^{152}$ See 1966 Senate Hearings on Fugitive Bailees, supra note 9, at 1.

${ }^{\text {Is }}$ See text accompanying notes $175-80$ infra. 


\section{A. Rapid Pretrial Release}

Three types of reforms will help to secure the rapid pretrial release of the one-third of arrestees who now remain in jail longer than 24 hours, partially or primarily because of financial problems. ${ }^{154}$ First, some arrestees spend unnecessary time in jail merely because of their own ignorance. Officials' reliance on inmates, the jail house lawyers, to inform new arrestees of their legal right to release on bail and of the practical procedures and cost of securing such pretrial release does not produce satisfactory results. The bondsmen cannot solicit the arrestee's patronage directly. ${ }^{155}$ Therefore, as part of the booking process, the booking officer should inform each arrestee of his right to bail, the cost of a bail bond, the collateral requirements which prevail in the community, and the procedures involved in obtaining an OR release. He could give this information orally, or to assure uniformity and comprehension, could distribute a printed explanation, in English and Spanish, on the back of the booking sheet or some other form which each prisoner receives. ${ }^{156}$

A second reform is to reduce the number of arrestees legally ineligible for release on bail. Arrestees legally ineligible for bail generally fall into three categories: Those charged with a capital offense; ${ }^{157}$ the accused felon who has not yet been arraigned; ${ }^{158}$ and the arrestee taken into custody by virtue of a warrant which either specifies no bail or orders the arrestee held for transfer to another jurisdiction. ${ }^{159}$ Short of a constitutional amendment giving him the right to bail, or an equally unlikely amendment to Penal Code section 1270 conferring the privilege of bail upon him, little can be done for the accused capital offender. ${ }^{160}$ However, to facilitate release of the remaining felony offenders, some counties have developed an informal and extralegal bail schedule for felony offenses. ${ }^{161}$ The legislature should investigate this practice and legitimize it if it adequately protects society while fulfilling a necessary function. Also, magistrates should be reluctant to issue warrants which do not specify an amount of bail. This practice causes particularly acute

${ }^{154}$ See text accompanying notes 113-17, 119 supra.

${ }^{135}$ CAL. Admin. CodE tit. 10, $\S \S 2079-79.5$ (1953). However, bondsmen may advertise their services. See, e.g., San Francisco Telephone Directory-Yellow Pages 174 (Sept. 1967) (Don't perish in jail-call Barrish for bail); id. at 175 (Don't be part of the "in" crowd-bail out).

${ }^{156}$ See Brodie, Bail in California, supra note 9, at 4.

${ }^{139}$ Cal. Pen. Code $\$ 1271$ (West 1956).

${ }^{13}$ See id. $\S 1269$ b (West Supp. 1967).

${ }^{159}$ See id.

${ }^{160}$ See text accompanying note 24 supra.

${ }^{16}{ }^{16}$ Kutchins interview, supra note 67. 
problems if the defendant is arrested in a county outside the magistrate's jurisdiction; he may have to spend several days in custody awaiting transfer back to the issuing magistrate's jurisdiction before that court will set his bail.

Third; the transient presents a perplexing and perhaps insoluble problem for the bail and OR release systems. Although he is as legally eligible for release on bail or OR as any other citizen, as a practical matter he has very little chance of finding a professional bondsman who will post a bond with less than 100 percent collateral security. He likewise is generally a poor risk for an $O R$ release, since most $O R$ programs look only to the defendant's community ties within the county in which he is arrested. Some bondsmen do provide a service for defendants who have community ties in another county or state. The California bondsman will contact a bondsman in the transient's home town and may post a bond if the defendant gets a good recommendation. ${ }^{162}$ OR program administrators should develop similar procedures, relying either on OR program investigators in the defendant's home town or the local police to verify the information which the arrestee provided.

\section{B. Avoidable Bail Forfeitures}

The state could avoid many bail forfeitures resulting from firsttime arrestees failing to appear by alleviating their fears and ignorance. If the new arrestees received better treatment while they were in jail pending release on bail and more accurate information about the California corrections system, they might not be so likely to become fugitives. Adoption of penal sanctions for bail jumping might further deter the arrestee's urge to flee. :

The state could eliminate the problem of the criminal who regularly jumps bail by forthrightly adopting a system of preventive detention which would deny the right to pretrial release altogether to this class of defendants. A slightly less effective sub rosa substitute would be to set bail. so high that the would-be jumper is unable to provide sufficient collateral to induce the bondsman to take a chance on him. However, in addition to the constitutional problems inherent in such a procedure, ${ }^{163}$ there may be serious practical difficulties in accurately defining the class of professional criminal and in accurately assigning particular defendants to that class.

The state could reduce, if not completely solve, the problem of the defendant who unintentionally fails to appear because of ignorance or

\footnotetext{
${ }^{162}$ See Brodie, Bail in California, supra note 9, at 13.

${ }^{16}$ See Comment, Preventive Detention Before Trial, 79 Harv. L. Rev. 1489, 1494 (1966).
} 
mistake by adopting the notification procedures which the OR projects ${ }^{164}$ and some bondsmen utilize. ${ }^{165}$ Each client receives notification by letter, telephone, or pcrsonal visit one or two days in advance of his scheduled court appearance. This procedure produces satisfactory results for the OR projects, although their selection process may give them. a generally more responsible group of clients than those left for the bondsman. To be success ful, this notification procedure requires a considerable amount of effort, and many bondsmen are unwilling to take the trouble. If the courts, the Department of Insurance, and the legislature feel that the results to be achieved, in terms of orderly court schedules and administrative convenience, are worth the bondsmen's effort, they could take several steps to stimulate the bondsmen's interest in notifying their clients of court dates. The court could require evidence of a letter, telephone call, or visit to each defendant reminding him of his obligation to appear, as proof of the bondsman's nonconnivance in the failure to appear, and either refuse to set aside the forfeiture entirely or retain a certain percentage of the bond as a penalty assessment. To prevent the bondsman from routinely passing this penalty cost on to the guarantors who put up collateral to secure the bond, the Department of Insurance could amend the Administrative Code ${ }^{166}$ to require the bondsman to show satisfactory evidence of his timely attempts to notify and remind his client of his duty to appear at the scheduled place and time as a condition precedent to his right to recover the additional cost from the guarantor. The legislature could a mend section 1305 of the Penal Code ${ }^{167}$ to provide that the bondsman has the duty to make a good faith effort to remind the principal, by appropriate means and within a reasonable time prior to each required appearance, of his obligation to appear at the specified time and place.

\section{Administrative Regulations}

\section{Regulate Out-of-State Recapture Practices}

The present recapture system gives the fugitive who jumps bail no procedural safeguards if the California bondsman recaptures him outside the state. This system may have a slight effect in discouraging fugitives from leaving California. However, it is highly unlikely that

${ }^{154}$ Kutchins interview, supra note 67.

${ }^{165}$ Donaldson interview, supra note 132.

${ }^{166}$ CAL. ADMIN. CoDE tit. 10, $\$ 2081$ (1953) allows the bondsman to recover from the guarantor the costs incurred in a recapture attempt, in addition to the amount of the forfeiture.

${ }^{167}$ This section specifies the remission of forfeitures provisions. See text accompanying notes $67-$ 75 supra. 
potential fugitives ever consider the possible loss of procedural rights as a factor in deciding whether to jump bail. By providing appropriate penal sanctions for bail jumping and by increasing those sanctions for fugitives who flee from the state, the state could create a more effective deterrent. ${ }^{168}$ This would be a more satisfactory approach to the problem than the present practice of turning the out-of-state fugitive over to the unregulated mercy of the professional bail bondsman or skip tracer. The Insurance Commissioner should promulgate regulations governing the conduct of bondsmen and their agents in tracking down and recapturing fugitive clients, and enforce these regulations with the sanction of license suspension or revocation.

\section{Publicize the Rights of Clients and Guarantors}

As a condition to obtaining a license in California, professional bail bondsmen must file a performance bond in the state's favor. ${ }^{169}$ The bond is conditioned upon the proper application and disposal of all money collected or received by the bondsman or his employees. Any person suffering damage or loss caused by a bondsman may bring an action against the bondsman and his surety on that bond. However, few people

\footnotetext{
${ }^{168}$ It is a federal offense punishable by a $\$ 5,000$ fine or five years in prison to flee across a state line to avoid prosecution for a felony. 18 U.S.C. $\S 1073$ (1964). This statute is used by district attorneys as the equivalent of a state bail jumping statute whenever possible, but an Assistant United States Attorney in San Francisco estimated that less than 10 percent of the interstate bail jumpers in Northern California are charged with this violation. Interview with David Baneroft, Assistant United States Attorney for Northern California, in San Francisco, January 24, 1968 (on file with the California Law Review). The United States Attorney will not issue an unlawful flight warrant if the local district attorney is unable to show reasonable grounds for believing that the fugitive fled interstate. Id. However, if the district attorney definitely knows that the defendant is in an out-of-state city, the $\S 1073$ warrant will be denied as unnecessary, since the distriet attorney can utilize reciprocal extradition procedures to get the local police to arrest the fugitive. Id. Morcover, the United States Attorney will not issue a $\$ 1073$ warrant in the following situations: Cases of child abduction by parents (official Justice Department policy); cases of bad checks on insufficient funds, unless the fugitive is clearly "an interstate paper hanger" (a local administrative policy, since "the FBI is not a credit agency"); and generally any nonseriou: felony. Id. Of the $100 \S 1073$ unlawful flight warrants issued in Northern California each year, 90 are for bail jumping and the other 10 are usually for fugitives who fled prior to their arrest. The FBI is quite effective in locating these fugitives-of the 300 fugitive cases in the past three years, less than 30 are still at large. However, the fugitive who is arrested by the $\mathrm{FBI}$ on a $\S 1073$ warrant is almost never prosecuted on the federal charge. Since these warrants are only issued for serious felonies, the fugitive already faces a stiff state penalty on the original charge, and the additional federal penalty would be "gilding the lily." Id.

There have becn few prosecutions under the federal bail jumping statute, 18 U.S.C. $\$ 3150$ (1964) (one prosecution every few years in Northern California) because of this gilding the lily philosophy and also because it is hard to prove that the bail jump was willful. The United States Attorney normally prosecutes for a federal bail jump only if the fugitive is acquitted on the original charge. Bancroft interview, supra.
}

${ }^{169}$ CAL. INS. CODE $§ \S 1802,1802.5$ (West 1955, as amended, West Supp. 1966). 
who deal with bondsmen, either as clients or guarantors, seem to know of their right to recover losses against this bond. ${ }^{170}$

Likewise, few people seem to know of the existence of citizens' department receives roughly 80 citizen complaints concerning bondsmen each year. ${ }^{171}$ Most of these complaints concern the bondsman's alleged failure to return collateral after surrendering the client or securing the exoneration of the bond. ${ }^{172}$ Few complaints come from the arrestee himself. The department attributes the small number of complaints received to public ignorance of the existence of a state agency which polices the activities of bondsmen, and to the attitude of some clients who would not think of complaining to a state agency even if a bondsman mistreated them. ${ }^{173}$

A simple reform would help to reduce public ignorance about existing administrative grievance procedures and remedies. The lnsurance Commissioner currently must approve every form and document which professional bondsmen use. ${ }^{174}$ The Commissioner should immediately require that all documents the bondsmen give to their clients and guarantors contain, in large bold face type, information on the right to recover against the bondsman's performance bond, and information on where to send complaints about treatment received from the bondsman. Because of the abuses which might be uncovered or deterred, this reform would also have the incidental effect of giving the Commissioner more thorough control over the bondsmen's activities.

\section{Obtain Adequate Information on the Bail System's Performance}

The retrieval function which professional bail bondsmen allegedly perform is one of the major justifications which spokesmen for the bondsmen advance for continuing their role in the administration of criminal justice in California. ${ }^{175}$ However, there is no accurate and comprehensive statistical information on a statewide basis as to the adequacy with which bondsmen are performing this function. This lack of information makes analysis of the utility of bondsmen and the bail system difficult. It also indicates that none of the state agencies charged

${ }^{170} \mathrm{Cf}$. W. Gellhorn, When Americans Complain 153-54 (1966).

"'Donnachie interview, supra note 55; interview with Angele Khachadour, counsel for the California Department of Insurance, in San Francisco, August 29, 1967 (on file with the California Law Review).

${ }^{12}$ Khachadour interview, supra note 171.

${ }^{13} / d$.

"CAl. Admin. Code tit. 10, § 2095(l) (1953).

${ }^{173}$ See Murphy, supra note 20, at 403; Brodie, Bail in California, supra note 9, at 24. 
with the duty to oversee and regulate the bail bond business have taken the trouble to accumulate adequate information on which to base their regulative policies. Unquestionably, bondsmen do return some fugitives for trial without cost to the state. But without statistical verification, the professional bondsman's alleged utility to the state as a retriever of fugitive clients is a slender reed, indeed, on which to base a legislative policy decision to retain the present system.

Two specific reforms will correct this information gap. First, the California Department of Insurance should require every licensed bondsman doing business in this state to submit a monthly report showing separately for both state and federal courts: (1) The number of bonds he has posted; (2) the face value of those bonds; (3) the amount of premiums he has collected; (4) the value of collateral his guarantors have put up; (5) the number of forfeitures which the courts have entered against him; (6) the number of summary judgments he has paid to the courts after the 180 day remission period has passed; (7) the number and timing of the forfeitures set aside and the reasons therefor; and (8) the number of defendants he or his agents have returned to the court from within and without the state. ${ }^{176}$ The general agents of the surety companies engaged in the bail bond business in California should prepare similar reports.

The second reform consists of modifying the monthly report to the Judicial Council of California submitted by the clerks of the superior, municipal, and justice courts from each county ${ }^{17}$ to include information on: (1) The number of bail bonds posted in the county; (2) the value of the bonds posted; (3) the number of forfeitures entered; (4) the number of forfeitures set aside within the 180 day remission period with the reasons therefor; and (5) the number and value of summary judgments obtained against the surety companies. This report might also indicate the number of defendants released on their own recognizances, the number refused $O R$ release, and the number of $O R$ failures. It could also indicate the number and value of cash bails posted, forfeited, and remitted. To insure complete coverage, the Judicial Council could request the clerks of the federal courts in California to submit the same information as a courtesy gesture.

The bondsmen and county clerks can furnish these reports to the state agencies with relatively little expense or effort, since all of the

\footnotetext{
${ }^{176}$ The accuracy of this report could be verified by cross-checking against a similar bail bond report which might be filed with the California Judicial Council by the county clerks, see text accompanying note 168 infra, and by occasional spot-check audits of the bondsman's and general agent's books.

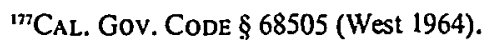


information is or should be readily available at the individual agent ${ }^{178}$ and county office level. ${ }^{179}$ Compiling statewide totals would provide a double entry source of reasonably accurate information about the California bail bond business and its role in the administration of justice. ${ }^{180}$ The bondsmen's reports could be quite helpful in alerting the Insurance Commissioner and the courts to long term trends and to sudden changes in the volume and nature of the bonds each bondsman writes. This would serve as an additional check on illegal steering practices by jailers and court personnel. Since a substantial amount of bail premiums are paid in cash, these reports from the bondsmen might prove to be of interest to the state and fejderal tax officials. The accumulation and verification of bail bond forfeiture and remission statistics on a statewide basis would be a valuable source of information for further research into the functioning of the bail bond business in California, and would provide useful tools for legislative investigation and reforms. This information should be correlated with available statistics on the number of defendants awaiting trial to determine the effectiveness of the pretrial release system.

\section{IV}

\section{ALTERNATIVES TO THE CALIFORNIA PRETRIAL RELEASE SYSTEM}

Several bail reform projects have been operating in various jurisdictions in the past few years. Two in particular have produced workable alternatives or supplements to pretrial release on bail.

\section{A. The Illinois 10 Percent Bail Deposit System}

lllinois has eliminated the professional bail bondsman from the administration of criminal justice. ${ }^{181}$ Instead of paying a nonreturnable 10 percent premium to the bondsman for posting a bail bond, the defendant deposits his 10 percent premium with the court. ${ }^{182}$ The state uses a carrot and stick approach to induce the compliance of the

\footnotetext{
"Some bondsmen make a weekly report to their general agent on the number of bonds written and the number of forfeitures exonerated. Hammel interview, supra note 77.

${ }^{179}$ The author was able to gather information for many of these categories at the offices of the municipal court clerks of San Francisco and Sacramento Counties.

${ }^{180}$ The Department of Insurance currently obtains a roughly comparable report from a few bondsmen who are being subjected to special scrutiny. For example, a bondsman who used to work as a peace officer, jailer, or court clerk may be given a restricted license for a two year period, and may be required to submit reports showing the referral source for each bond he writes. The purpose is to restrain his natural temptation to exploit his personal contacts with his former fellow employees. Khachadour interview, supra note 171.

${ }^{131}$ See 1965 Senate Hearings, supra note 11, at 193 (testimony of Professor Charles Bowman). 13238 IlL. ANN. STAT. ch. 38, § 110.7 (Smith-Hurd 1964), as anended, (Supp. 1967).
} 
defendant with the orders of the court. The stick takes the form of the familiar financial and criminal penalties for willful failure to appear, but the carrot gives the defendant a new incentive to appear-a chance to obtain a 90 percent refund of his premium deposit. ${ }^{183}$ If the defendant appears in court as required and complies with all requirements, the court keeps 10 percent of the deposit to cover administrative expenses and returns the remainder to the defendant. For example, if a one thousand dollar bond is set, the defendant can obtain his release by depositing 100 dollars with the court, and upon appearing for his trial, he gets a 90 dollar refund. This prospect of direct financial gain to the defendant should be a more effective means of obtaining his presence in court on schedule than the threat of loss of collateral. ${ }^{184}$ Preliminary reports on the operation of the new system indicate that it functions adequately. ${ }^{185}$ Apparently the performance of the system was satisfactory enough that in 1965 the Illinois legislature took the next step and abolished the professional bail bond business in that state. ${ }^{186}$

\section{B. The Federal Bail Reform Act of 1966}

The purpose of the Federal Bail Reform Act of $1966^{187}$ is to insure that no person, regardless of his financial status, is needlessly detained pending trial if detention does not serve the public interest or the ends of justice. The Act provides for the defendant's release in noncapital cases

${ }^{183} \mathrm{Id}$. $\S 110.7(\mathrm{f})$. According to Professor Charles Bowinan, who chaired the committee which developed the Illinois plan, a realistic approach to the problem of bail involves three fundamental premises:

(1) Factual studies prove that the great majority of persons released on bail have no intention of violating bail and will appear for trial. For this majority, OR release is most appropriate.

(2) To the extent that pecuniary loss is a deterrent, such financial loss should be minimized in the case of the person who does appear for trial. Therefore, the refund provision is appropriate.

(3) A person who will jump bail is not deterred by the prospect of pecuniary loss to himself or anyone else so that other deterrents are required-i.e., criminal penalties for nonappearance. See Committee Comments, 38 ILL. ANN. STAT. at 147 (Smith-Hurd 1964).

${ }^{184}$ See Ervin, The Legislative Role in Bail Reform, 35 GEO. WASH. L. REV. 429, 436 (1967).

${ }^{13 s}$ See 1965 Senate Hearings, supra note 11, at 191-92 (testimony of Professor Charles Bowman); 1965 SENATE STAFF RePORT, supra note 4, at 17. One minor problem (or advantage) of the new system is that some defendants' lawyers are attaching the 10 percent deposit to assure payment of their fee. 1965 Senate Hearings, supra note 11, at 130 (testimony of Carroll Stewart, Kentucky bondsman).

About three percent of those released under both the 10 percent plan and the OR release plan in Illinois eventually jump. Professor Bowman comments that these are "the hard-core jumps who are going to jump under any system devised." Letter to the author from Charles Bowman, professor of law at the University of Illinois (on file with the Californin Law Review).

${ }^{186}$ 1965 Senate Hearings, supra note 11, at 193 (testimony of Professor Charles Bowman). According to Professor Bowman, 1 llinois can, and does, get along without the bondsmen.

${ }^{187} 18$ U.S.C. $\$ \S 3146-52$ (Supp. I1, 1965-66). For a discussion of the legislative history of this Act, see Ervin, supra note 175. 
on his own recognizance or upon an unsecured personal appearance bond, unless the magistrate determines that this will not reasonably assure the defendant's presence at his trial. ${ }^{18}$ In such a case, the magistrate may impose additional conditions upon the defendant's release in the following order, singly or in combination:

(1) Place the person in the custody of a designated person or organization agreeing to supervise him;

(2) Place restrictions on the person's travel, association, or place of abode during the period of release;

(3) Require the execution of an appearance bond in a specified sum and the deposit in the registry of the court, in cash or other security as directed, of a sum not to exceed ten percent of the amount of the bond, such deposit to be returned upon the performance of the conditions of release;

(4) Require the execution of a bail bond with sufficient solvent sureties, or the deposit of cash in lieu thereof; or

(5) Impose any other conditions deemed reasonably necessary to assure appearance as required, including a condition that the person return to custody after specified hours. ${ }^{189}$

The Act further provides for an automatic review of the conditions of release if the defendant is still in custody after 24 hours. Willful failure to appear is either a misdemeanor or a felony, depending upon the original charge. ${ }^{190}$ Upon conviction, the defendant receives credit toward service of sentence for any time served in pretrial custody. ${ }^{191}$

Under this system, release without money is the normal procedure, not the exception. ${ }^{192}$ The emphasis shifts from release of specially qualified defendants on OR to the release of all defendants on conditions appropriate to their individual risks. ${ }^{193}$ The primary sanction against fugitives is criminal prosecution rather than forfeiture of bail.

The drafters of the Federal Act intendcd it to be the model for comparable reforms of state pretrial release systems, ${ }^{194}$ and some states have already followed the federal plan. ${ }^{195}$ This system differs from the

1"s 18 U.S.C. $\$ 3146($ a) (Supp. II, 1965-66).

${ }^{18 \%} / d$.

191d. $\$ 3150$.

${ }^{191} I d$. $\S 3568$. For a more detailed discussion of the provisions of the Act, see Comment, The Bail Reform Act of 1966, 53 Iowa L. REv. 170, 180-88 (1967).

${ }^{192}$ Wald \& Freed, The Bail Reform Act of 1966: A Practitioner's Primer, 52 A.B.A.J. 940, 941 (1966).

${ }^{193} / d$. "The Commissioner can look to a variety of sources for information: arresting officer, prosecutor, probation officer, U.S. marshall, the accused, or his attorney." Id. at 942.

${ }^{194} / d$. at 940.

${ }^{19}$ See, e.g., Spangenberg, Homans, \& Flaschner, Bail Reform in Massachusetts, 1965-1967. 52 MASS. L.Q. 135 , 146 (1967). 
present California pretrial release system primarily in emphasis and in the number of nonmonetary conditions which are available to the conscientious magistrate. ${ }^{196}$

\section{CONCLUSION}

This Comment has described the theory of the California bail bond system and examined the manner in which the system performs its release and return functions, in order to provide a factual basis for rational consideration of possible alternative procedures. Surveys indicate that with the presently available mix of pretrial release procedures, roughly two out of every three persons who are formally arrested and booked are able to obtain release from jail within 24 hours. Somewhere between four and thirteen percent of the total number arrested are unable to secure release within 24 hours solely or primarily because they cannot afford a bail bond. Therefore, one criterion for evaluating the relative merits of suggested alternatives to the California bail system is whether the percentage of arrestees remaining in jail because of inability to "buy their freedom" could be significantly reduced, without sacrificing speedy release for those currently able to obtain it under the existing system.

Another criterion for comparison is the cost of the alternative release systems and the allocation of the cost burden. Under the present system, the accused or his family and friends bear most of the cost directly. The major direct cost to the state is providing detention facilities for those arrestees who cannot secure release on bail or on their own recognizance. Analysis of published cost figures for several OR projects suggests that, at least at the pilot program stage, the cost per arrestee released was quite high. ${ }^{197}$ Some bondsmen have suggested, perhaps not entirely facetiously, that it would be cheaper for the state to pay the bail bond premium for the relatively small number of arrestees who are now unable to purchase their release, rather than set up an entirely new and expensive system to process all applicants for pretrial release. ${ }^{-198}$ This suggestion actually strikes at one of the basic principles of the bail system. If the indigent bailee who has no financial stake at all in returning to court is just as likely to return as the client who has pledged

\footnotetext{
${ }^{195}$ The Department of Justice is now compiling statistical information on the functioning of the Federal Bail Reform Act. However, no results as yet have been published. Letler to the author from Fred M. Vinson, Jr., Assistant Attorney General, Criminal Division (on file with the California Law Review).

${ }^{197}$ California Bondsmen's Bail Testimony, supra note 8, at 11-14.

${ }^{192}$ Perry interview, supra note 32.
} 
his own or his family's property as collateral on the bond, the entire financial-interest apparatus of the bail system is unnecessary.

A third criterion is the relative forfeiture rates and the equally important remission rates under the present system as compared with possible alternatives. The ultimate purpose of a successful pretrial release program is not only to release as many arrestees as rapidly and as cheaply as possible, but also to insure that a reasonably large percentage will return on schedule for their trials. Therefore, a comparison of pretrial release procedures should begin with these four points: How many arrestees get out, how quickly, at what cost, and how many reappear for trial.

It is clear that substantial improvements in the operation of the present pretrial release system in California are both necessary and possible. This Comment has proposed the following specific reforms and suggestions as solutions to some of the structural and administrative problems which now exist in the system. First, the presently available alternatives to release on bail need improvement and more frequent use. District attorneys and police officials should encourage the use of the station house release procedure, and should develop guidelines for using the citation in lieu of arrest procedure. Improved machinery to process more rapidly applications for release on the defendant's own recognizance is needed. The magistrate should not limit the scope of his consideration of the OR applicant's community ties to the county where the arrest occurred, but should look to the defendant's record of stability wherever he makes his home.

Second, the bail setting process needs an overhaul. Machinery is needed to provide quickly verified information on each defendant appearing before the magistrate to have bail set. There should be a provision for an automatic review of the bail amount in cases where the defendant is unable to secure his release within a week or 10 days. This would tend to mitigate the problems resulting from the effective delegation of the decisionmaking power on release to the professional bail bondsman. The Judicial Council of California should impose appropriate sanctions and the appellate courts should enforce the prohibition against resetting bail in a higher amount simply because the defendant on a misdemeanor charge requests a jury trial.

Third, the courts should launch a two-pronged attack on the problem of arrestees remaining in jail because they are ineligible for rapid release on bail. They should consider and test a bail schedule for nonviolent felonies, and should carefully review each request for a nobail warrant or a no-bail hold for another jurisdiction. The defendant 
should receive credit for any time spent in pretrial detention against the eventual sentence or fine.

Fourth, jail administrators should immediately correct the problem of arrestees remaining in jail because they do not know of their right to bail or how to get it. The booking officer should provide information in writing on the bail and OR release procedures to each arrestee at the time of booking.

Fifth, the legislature, the courts, and the jailers can reduce the number of bail forfeitures in three ways: (1) The legislature and the courts should encourage or compel the bondsmen to adopt the notification procedures which the OR release projects successfully use to prevent their clients from forgetting about their duty to appear as scheduled. This might also stimulate the bondsmen to perform more adequately their custodial and supervisory functions. (2) The courts and the jailers should reduce the first-time arrestee's fears of the unknown criminal corrections process by improving communications and by providing clear information as to what is likely to happen in the event of detention. Jailers should improve the physical condition of pretrial detention. (3) The legislature and the courts might curb the bail-jumping proclivities of professional criminals by the forthright adoption of a policy of preventive detention.

Sixth, the legislature should immediately restrict the bondsman's power to pursue and arrest his fugitive clients outside the state without being subject to effective regulation and without providing adequate procedural safeguards for the fugitive. The legislature should provide penal sanctions as a more effective deterrent to bail jumping. The Insurance Commissioner should promulgate administrative regulations and enforce them with appropriate sanctions against the bondsman and his agents in order to control his recapture practices.

Seventh, the bail forfeiture and remission procedure operates fairly effectively to provide bondsmen with an incentive to return fugitive clients to court. Judges should permit the interested bondsman to appear in court without an attorney to move for the remission of a forfeited bond, since he bears the burden of loss if the forfeiture is not set aside.

Eighth, the California Department of Insurance should take steps to publicize more effectively existing channels which process citizens' complaints against bail bondsmen and to emphasize the citizens' right to recover against the bail bondsman's performance bond. Appropriate notices printed on all documents which the bondsmen now provide their clients and guarantors could accomplish these objectives.

Finally, to provide accurate and comprehensive factual information about the present system's functioning, the California Insurance 
Commissioner and the California Judicial Council should compile detailed monthly reports from each bail bondsmen and the courts.

In view of the studies conducted in San Mateo, San Joaquin, Fresno, and Kings Counties, it appears that the present California bail system functions fairly well. If the legislature were to adopt these suggested reforms it could both alleviate most of the present inequities in the system and gain sufficient reliable information to make a responsible judgment about the wisdom of retaining the system, or of adopting an alternative such as the federal bail plan or the Illinois 10 percent plan. 